\title{
Thirty years of research and development of Lagrangian buoys at the Institute of Marine Sciences
}

\author{
Emilio García-Ladona, Joaquim Salvador, Pere Fernandez, Josep L. Pelegrí, Pedro Elósegui, \\ Oriol Sánchez, Jose Antonio Jiménez Madrid, Fernando Pérez, Joaquim Ballabrera, \\ Jordi Isern-Fontanet, Jordi Salat, Jordi Font \\ Dept. of Physical and Technological Oceanography, Institut de Ciències del Mar, CSIC, Passeig Marítim, 37-49, \\ 08003 Barcelona, Spain.
}

\begin{abstract}
Summary: Since the mid-1980s, physical oceanographers at the Institute of Marine Sciences have been involved in the use of Lagrangian drifters as a complementary technology for their oceanographic research. As Lagrangian observations became more feasible, these researchers continued developing their own drifters in what was to be the seed of current technological activities at the Physical and Technological Oceanography Department. In this paper we overview the work done during the last 30 years with special focus on Lagrangian developments from the initial activities to the latest developments. In addition to basic oceanography research applications, Lagrangian technological developments include prototypes for measuring surface and subsurface ocean properties, for tracking purposes in search and rescue operations and pollution events, and for monitoring ice motion and thickness in the Arctic. The paper emphasizes original and unpublished technical aspects related to the latest developments.
\end{abstract}

Keywords: Lagrangian drifters; sea surface measurements; salinity measurements; oil spills drifters; SMOS.

Treinta años de investigación y desarrollo de boyas Lagrangianas en el Instituto de Ciencias del Mar

Resumen: Desde mediados de la década de los 80, los oceanógrafos físicos en el Instituto de Ciencias del Mar se involucraron en el uso de boyas Lagrangianas como una tecnología complementaria para su investigación oceanográfica. A medida que las observaciones Lagrangianas se volvieron más factibles, los investigadores continuaron desarrollando sus propios flotadores en lo que se convirtió en la semilla de las actuales actividades tecnológicas llevadas a cabo en el Departamento de Oceanografía Física y Tecnológica. En este artículo se presenta una visión general del trabajo realizado durante los últimos 30 años, con especial énfasis en el uso de flotadores a la deriva y desarrollos propios desde su inicio hasta las aplicaciones más recientes. Además de estudios básicos de investigación oceanográfica, los desarrollos tecnológicos llevados a cabo incluyen prototipos para medir las propiedades superficiales y sub-superficiales, para tareas de seguimiento en operaciones de búsqueda y rescate y eventos de contaminación marina o para monitorizar el grosor de la capa de hielo y su movimiento en el Ártico. En este trabajo se hace hincapié en aspectos técnicos originales e inéditos relacionados con los últimos desarrollos.

Palabras clave: flotadores Lagrangianos; medidas de la superficie del océano; medidas de salinidad; flotadores de vertidos de petróleo; SMOS.

Citation/Como citar este artículo: García-Ladona E., Salvador J., Fernandez P., Pelegrí J.L., Elósegui P., Sánchez O., Jiménez Madrid J.A., Pérez F., Ballabrera J., Isern-Fontanet J., Salat J., Font J. 2016. Thirty years of research and development of Lagrangian buoys at the Institute of Marine Sciences. Sci. Mar. 80S1: 141-158. doi: http://dx.doi.org/10.3989/ scimar.04325.14A

Editor: D. Vaqué.

Received: July 29, 2015. Accepted: February 23, 2016. Published: September 30, 2016.

Copyright: (C) 2016 CSIC. This is an open-access article distributed under the terms of the Creative Commons Attribution (CC-by) Spain 3.0 License.

\section{INTRODUCTION}

Since the pioneering work of John Crossley Swallow (1923-1994), Lagrangian buoys have been widely used to study and characterize large-scale and mes- oscale ocean currents and their influence on ocean mixing, as well as to infer dynamical properties of the ocean surface (Rossby 2007). With the advent of satellite tracking capabilities in the 1970s and the improvements in drifter design and battery capacity in 
the 1980s, drifting buoys became a valuable tool for sampling the ocean over a wide range of scales, from tidal/inertial to interannual scales and from a few to thousands of kilometres (Niiler 2003). In 1987, the World Climate Research Programme, coinciding with the setup of the World Ocean Circulation ExperimentTropical Ocean and Global Atmosphere (WMO 1988) programme, promoted an initiative to design, calibrate, deploy and distribute data from a global array of standard low-cost surface drifters using the ARGOS telemetry system (Niiler et al. 1987, Sybrandy et al. 1992, Niiler et al. 1995, Hansen and Poulain 1996). This was the precursor of the present Global Drifter Programme coordinated by the National Oceanic and Atmospheric Administration (http://www.aoml.noaa.gov/phod/dac/ index.php), which is aimed at monitoring with drifters as a relatively "low-cost" option for surveying and studying the near-surface dynamics of large and poorly known areas of the oceans (Lumpkin and Pazos 2007).

Initially drifters were used as water followers to map surface currents, characterize their variability and evaluate their turbulent behaviour (Richardson 1983, Davis 1985b). Soon, drifters evolved to carry onboard instrumentation, becoming a perfect platform to provide a Lagrangian picture of the measured parameters (Bitterman and Hansen 1993). Sea surface temperature (SST) was identified as a key variable and most of the drifting surface buoys deployed in several international programmes (e.g. TOGA [Tropical Ocean-Global Atmosphere programme], EPOCS [Equatorial Pacific Ocean Circulation Experiment], NORPAX [North Pacific Experiment]) were devoted to measuring SST and near-surface currents on a regular basis (Hansen and Herman 1989). In the early 1990s, an increased effort was made to extend the measures taken by surface drifters with salinity and bio-optical properties (Swenson et al. 1991, 1992, Abbott et al. 1995). The feasibility of attaching salinity devices to Lagrangian drifters was successfully explored following the attempts made with the Tropical Atmosphere Ocean moorings array (Mcphaden et al. 1990, Swenson et al. 1991).

At the beginning of this century a new generation of profiling floats was developed to provide autonomous profiles of water-mass characteristics, in what became the heart of the Argo programme (Roemmich and Owens 2000, Davis et al. 2001). This programme, now at a mature stage, provided for the first time a quasiglobal picture of the subsurface temperature and salinity structure (Roemmich et al. 2009). The advance has been enormous: more than 3000 automatic profilers gather more than 9000 vertical profiles every month, covering almost the entire oceans. These numbers are inconceivable with classical conductivity-temperaturedepth (CTD) surveys using research vessels. However, almost no data are being gathered near the sea surface because, in order to reduce the risk of biological fouling in sensors, the pumping mechanism is switched off during the ascending phase a few metres before it reaches the surface. Further, because of their periodic vertical cycle, the profiling floats cannot be used to track water parcels. As a complementary approach, the European Space Agency started to promote the Soil Moisture and Ocean Salinity mission (SMOS) to retrieve, for the first time, synoptic measurements of sea surface salinity (SSS) and soil moisture from remote sensing. Oceanographers from the Department of Physical and Technological Oceanography at the Institute of Marine Science (DOFT-ICM) worked in the SMOS mission, and one of their main tasks was to develop Lagrangian buoys to validate the SS satellite measurements.

The DOFT-ICM was officially created in 2006 from the Physical Oceanography group, which was part of the former Marine Geology and Physical Oceanography Department at the Institute of Marine Sciences (ICM). With the incorporation of researchers from the Spanish Marine Technology Unit in 2013, the DOFT-ICM finally evolved to its present form. Some of the research carried out by DOFT-ICM oceanographers ran parallel to the international drifter developments, with Lagrangian measurements first used in the mid-1980s. In the framework of the Spanish-USA Joint Committee for Scientific and Technological Cooperation, Jordi Salat and Jordi Font (DOFT-ICM), Dong-Ping Wang (State University of New York) and Paul La Violette (Naval Oceanographic and Atmospheric Research Laboratory in Mississippi) carried out the first cruises to study mesoscale variability on the northwestern Spanish coasts. At this time much of the ocean research focused on studying mesoscale phenomena (eddies, filaments, etc.) as key mechanisms to understand shelf-slope exchanges associated with frontal structures (Font et al. 1988, Wang et al. 1988).

Among the first European based research initiatives, the Marine and Science Technology programmes allowed ambitious sampling experiments aimed at understanding the mesoscale variability of the circulation in the western Mediterranean Basin. The access to the worldwide satellite monitoring ARGOS system, together with the consolidation of the WOCE Surface Velocity Programme (WOCESVP) standard drifter attached to a holey-sock drogue (Sybrandy et al. 1992, Lumpkin and Pazos 2007), facilitated massive drifter deployments in undersampled regions such as the Algerian Basin. By the late 1990 s and the early 2000 s, the idea of remotely measuring the SSS as an important component of the Earth water cycle became consolidated within the international community. Work done at the DOFT-ICM during the Wind and Salinity Experiment showed the good correlation between radiometric salinity estimates and in situ measures at $0.2 \mathrm{~m}$ below the surface (Font et al. 2003, Camps et al. 2004, Gabarro et al. 2004). Simultaneously, the need to characterize the water-mass transformations in the subtropical eastern Atlantic Ocean required the ability to monitor salinity and temperature just below the mixing layer. While various commercial floats were available at that time, it was considered necessary to develop a new modular drifter that was able to make both surface and subsurface measurements in response to complementary requirements of various research projects.

In this manuscript, we review the Lagrangian research activities carried out by DOFT-ICM members over about 30 years, overviewing their technological 

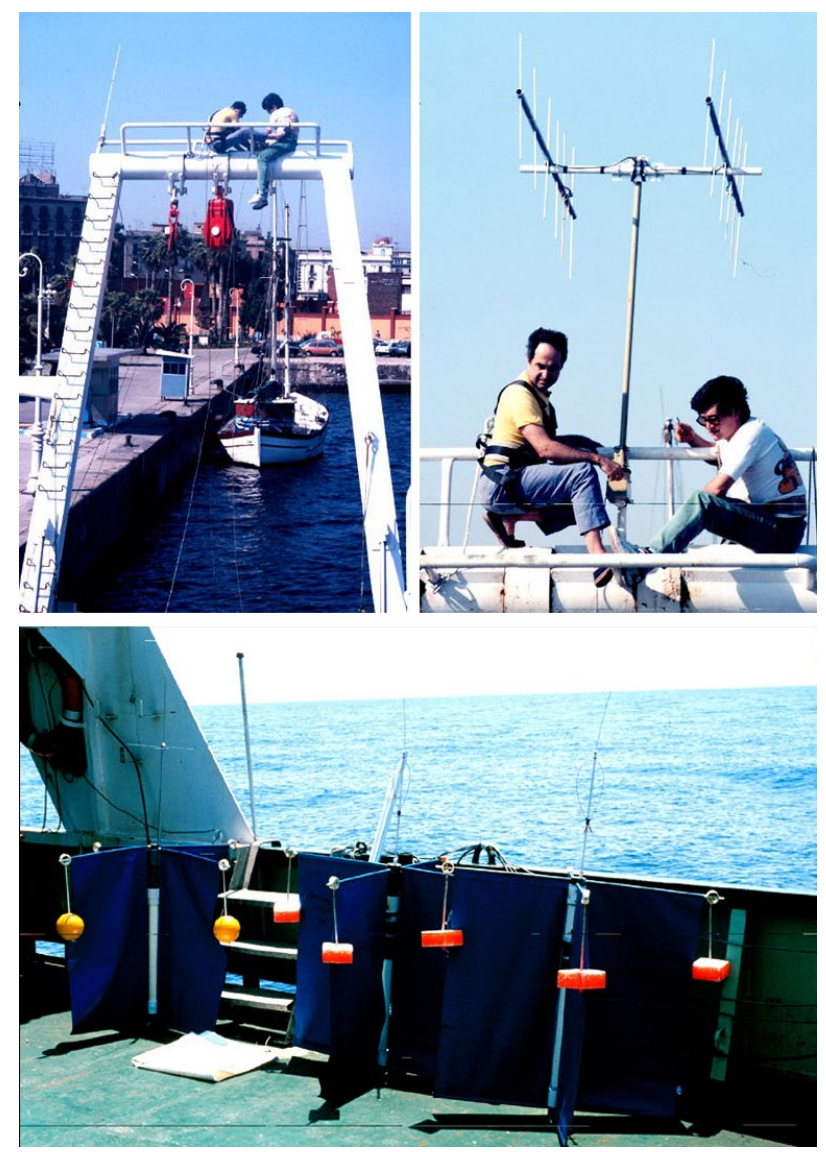

Fig. 1. - Left: Mario Vieira (Marine Sciences Research Centre, State University of New York) and Arturo Castellón (ICM, CSIC) installing the VHF antenna on top of the A-frame crane of R/V García del Cid. Right: a closer look at the VHF antenna for tracking drifters. Bottom: CODE-type drifters used during the FE87 cruise equipped with the characteristic long, thin cross-shaped VHF antenna.

developments in drifters. This paper does not follow a classical structure but has several subsections to summarize the contributions made in several research topics, from the initial contributions thanks to the pioneering work of Agustí Julià (1940-2009; Salat 2010) to the latest developments to monitor Arctic ice properties. We start by briefly reviewing the contributions and work on mesoscale variability and dynamics in the western Mediterranean Basin. Section 2 focuses on the ICM-AKP drifter design for SST and SSS measurements at a regional and global scale. In section 3, we summarize DOFT-ICM activities related to the Prestige accident and subsequent efforts aimed at improving the response to marine pollution events. We include a section presenting the latest technological contribution, the SATTICE buoys, developed to monitor ice properties in the Arctic (section 4), and we end up with a summary of major developments.

\section{MESOSCALE DYNAMICS AND WESTERN MEDITERRANEAN CIRCULATION}

As explained in the introduction, a joint SpanishUSA cooperation programme carried out a series of field experiments between 1986 and 1992 (hereafter FE86 to FE92), in which classical hydrographic sampling was combined with drifter deployment and a remote sensing survey of the Catalan Sea. The first reported use of drifters by DOFT-ICM researchers goes back to FE86. Four CODE-type drifters (Davis 1985a) were deployed and tracked onboard the R/V Garcia del Cid. At that time the tracking was done by detecting the VHF radiofrequency signal emitted by each drifter, detected through an antenna mounted on the vessel's A-frame crane (Fig. 1). The procedure was to follow drifters and detect the signal from at least two separate ship positions and then, through triangulation, to determine the fixing point. In order to retrieve the trajectory with this method, the ship must continuously follow the drifters during a certain period of time. The tracking extent and accuracy was limited by the degree of dispersion of drifter trajectories and by the ship's ability to move fast enough between consecutive tracking positions.

During the FE86 cruise, drifter observations showed how water parcels inside a filament of lowsalinity waters evolve faster than the advection of the structure itself, indicating strong convergence zones at the head of the filament (see Fig. 2, Wang et al. 1988). In 1987 a second cruise was undertaken slightly north of the FE86 area but still in the shelf/slope region close to the northwestern Spanish coast. Four drifters were combined with mooring observations and CTD casts to quantitatively measure the properties of windinduced near-inertial motions in a frontal area (Salat et al. 1992). Downward propagation of inertial energy was evidenced by an increase in the phase with depth of inertial motions. Both the observed subduction of low-salinity water in the frontal area and the downward propagation of near-inertial energy towards deeper layers highlighted the role of mesoscale phenomena as effective mechanisms of water and energy exchanges between the shelf and open ocean waters.

Four years later, the Mass Transfer and Ecosystem Response project in the framework of the European MAST programmes promoted the coordination of the European research community working in the Mediterranean. In this project a series of field cruises were conducted, including the DOFT-ICM contributions with the ALGERS'96 and ALGERS'98 experiments carried out respectively in October 1996 and May 1998 onboard the Spanish R/V Hespérides. These experiments were aimed at improving our understanding of the structure and variability of the Algerian Current (ALGERS'96), focusing on the structure and characteristics of Algerian eddies (ALGERS'98) commonly observed in infrared images and detected by the first TOPEX-POSEIDON altimetry missions. Whereas in the first DOFT-ICM Lagrangian studies only a few drifters were deployed as a complementary technique to traditional ship cruises, these experiments used a massive deployment of drifters to cover a wide region of difficult access with research vessels in order to characterize the statistical properties of the Algerian Current. In both cruises several WOCE-SVP standard drifters with the holey-sock drogue at $10 \mathrm{~m}$ were used as representative of the surface circulation not directly forced by the wind. In addition, at that time 

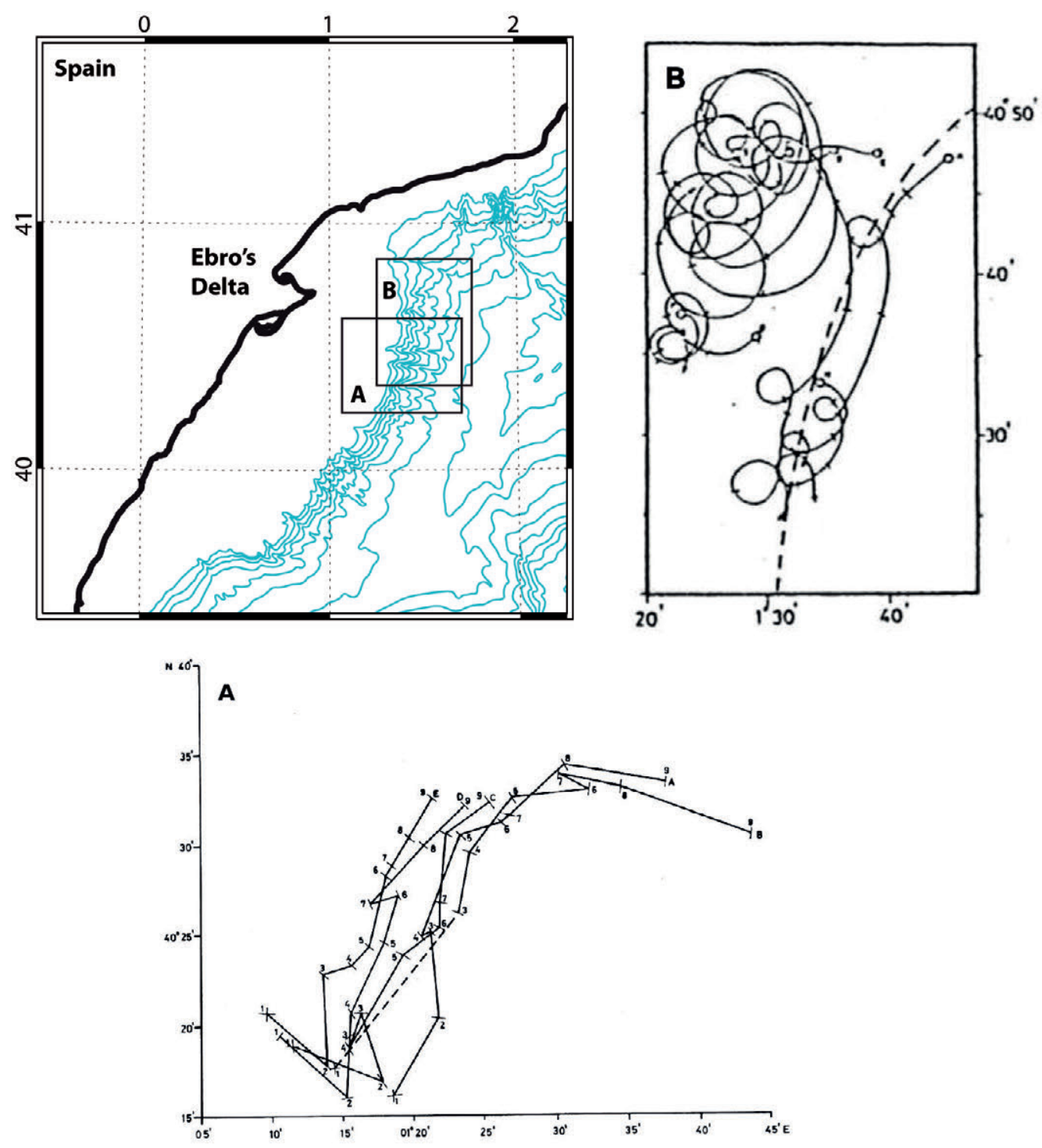

Fig. 2. - Left: general map of the areas sampled during the FE-86 (A) and FE-87 (B) cruises in front of the Ebro River (northwestern Mediterranean Basin). Centre: trajectories of VHF radio-tracked drifters inside a low-salinity filament in the northwestern Mediterranean region (reproduced with permission from Wang et al. 1988). Right: observations of inertial oscillations depicted by drifters deployed during the FE-87 cruise (reproduced with permission from Salat et al. 1992).

the ARGOS telemetry system was fully developed and implemented, facilitating the tracking of many drifters over longer periods and improving the accuracy over the earlier radio tracking techniques.

Instabilities of the Algerian Current often evolve into large coherent eddies that detach towards the central basin while strongly modifying the path of the Algerian Current. This was initially observed by (Millot 1991), who reported a drifter in the Algerian Current that suddenly deflected towards the north and reached the Balearic Basin. The detaching eddies are very coherent in time and space and can last for several months and even years propagating inside the Algerian Basin, so they play an important role as a transport mechanism of mass and energy (Isern-Fontanet et al. 2004). Their generation mechanisms and their evolution attracted the attention of researchers in the 1990s (e.g. Nihoul and Jamart 1989), but most of the studies focused on remote sensing data, laboratory and nu- merical experiments, and only a few dealt with their in situ characteristics (e.g. Benzohra and Millot 1995).

In ALGERS'96, 18 drifters were released at the place where the Algerian Current reattaches to the African coast after the Almeria-Oran front, near 0-1 ${ }^{\circ}$ E. This data set was used to build the first Lagrangian picture of the Algerian Current (see Fig. 3, Font et al. 1998), showing the progression of the mean surface circulation from the Alboran Basin to the Sicilia Strait, with no flow being deflected towards the Algerian Basin. Details on how instabilities grow and evolve into eddies and detach from the Algerian Current were documented and quantified (Salas et al. 2002). Statistical properties of the flow were also estimated from this set of trajectories. Characteristic integral scales and diffusivities were determined and the location of those regions with enhanced mesoscale variability (where eddy kinetic energy exceeds the mean kinetic energy) was found to be associated with places where instabili- 

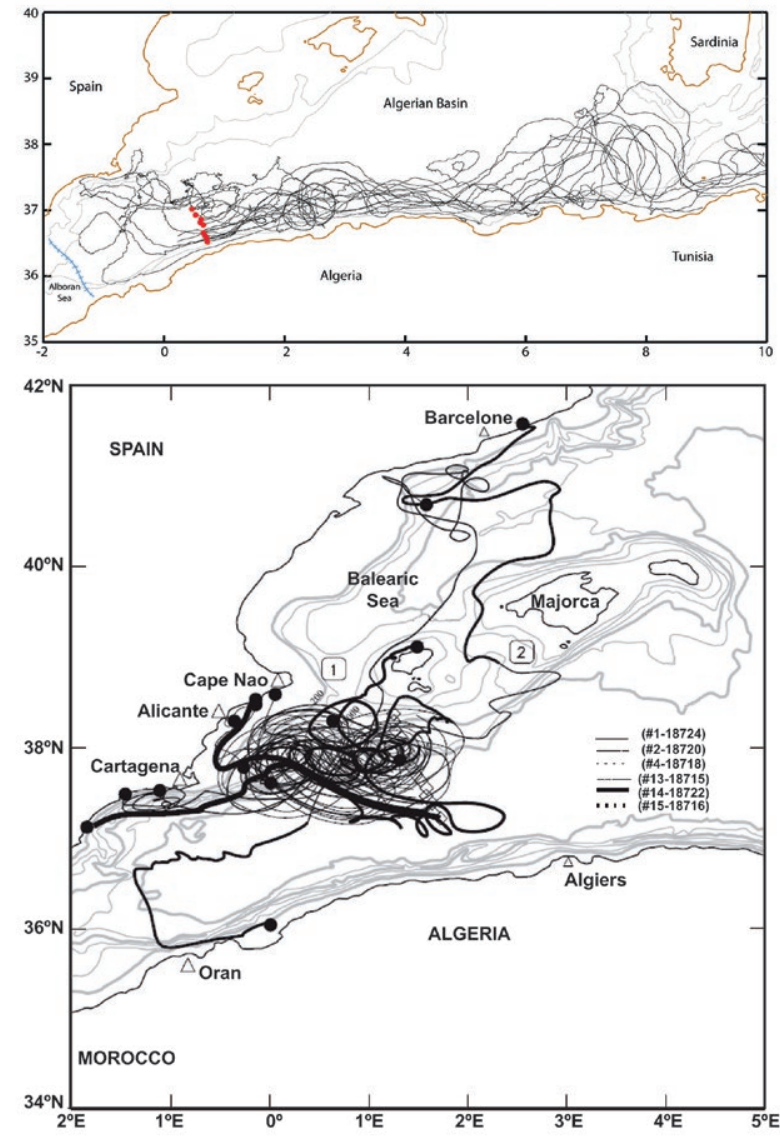

Fig. 3. - Top: spaghetti diagrams of drifters deployed during the ALGERS'96 cruise in October 1986 (adapted from Salas et al. 2002). Red dots indicate drifter deployment and the blue line with crosses around $36^{\circ} \mathrm{N} 1^{\circ} \mathrm{E}$ corresponds to the Almeria-Oran frontal zone. Bottom: trajectories obtained during the ALGERS'98 cruise in May 1998 (adapted from Salas 2003). Black dots correspond to the end points of drifter trajectories, labels within squares indicate the Ibiza (1) and Mallorca Channels (2) and triangles correspond to the main geographical features (cities and capes).

ties usually grow and develop (Salas et al. 2002). These instabilities were associated with episodes of enhanced fertilization inside the eddies increasing the biological productivity, a finding not accounted for in previous studies (Moran et al. 2001).

The ALGERS'98 cruise was explicitly organized to sample in detail the structure of an Algerian eddy. Through an intensive survey of thermal infrared images, a large eddy was detected south of the Balearic Islands and a ship cruise was carried out to sample its structure. For the first time, it was possible to characterize one of these mesoscale structures in detail: 15 standard WOCE-SVP drifters with a drogue centred at $10 \mathrm{~m}$ and deployed across its centre revealed a deep structure with surface velocities approximately in geostrophic balance and close to solid body rotation (Ruiz et al. 2002). The density distribution indicated a deepening of the isopycnals near the eddy's centre, at levels as deep as $1500 \mathrm{~m}$, where an associated anticyclonic circulation of about 5 to $10 \mathrm{~cm} / \mathrm{s}$ was detected. The eddy was located close to the Balearic shelf, strongly interacting with the shelf/slope and slowly evolving southwestward along the shelf-break (Salas 2003).

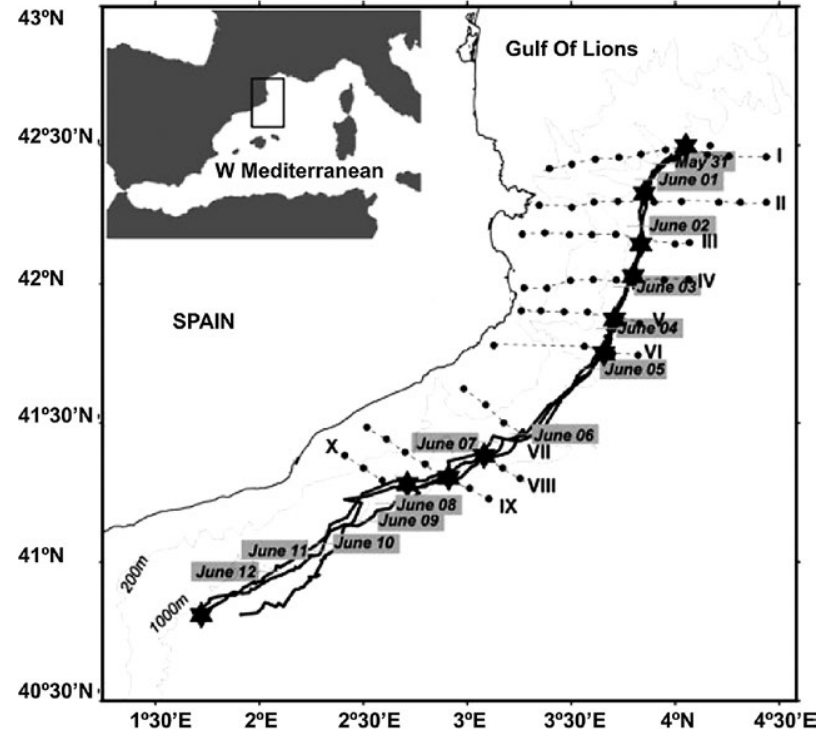

Fig. 4. - Drifter trajectories during the ARO-2000 cruise (reproduced with permission of Sabatés et al. 2007). Trajectories go from May to June 2000. Stars indicate the initial position of a series of hydrographic sections (roman labels) performed perpendicular to drifter trajectories.

In addition to these studies on mesoscale variability in the western Mediterranean, Lagrangian drifters started to be used as a proxy for the flow advection of living organisms. A first study aimed at assessing the relative importance of the advection by the Liguro-Provençal Current as a transport mechanism of anchovy larvae along the Catalan continental slope from the Gulf of Lions. Four WOCE-SVP drifters with a 4-m drogue centred at $10 \mathrm{~m}$ were deployed inside the core of low salinity waters and then tracked and followed for 10 days (Fig. 4). The Lagrangian experiment was complemented with hydrographic measurements and samples of zooplankton populations in a series of transects perpendicular to the drifters' paths. Anchovy larvae from the spawning area in the Gulf of Lions were advected towards the south, embedded into this plume of low salinity waters following a regular path; relative separation of drifters was less than $4 \mathrm{~km}$ during the 10-day experiments. The size increase of anchovy larvae throughout the Lagrangian tracking closely agreed with the general growth rate calculated through otolith analysis (Sabatés et al. 2007).

\section{REGIONAL AND GLOBAL CIRCULATION DYNAMICS}

The study of the global ocean dynamics using Lagrangian methods at the DOFT-ICM received a substantial boost in 2006 thanks to several projects funded by the Spanish National Research and Development Programme (MIDAS4 2005-2008; MIDAS5 20072011; MIDAS6 2011-2013; CANOA 2005-2009; MOC2 2009-2011; TIC-MOC 2012-2014). These projects essentially had very different goals, yet they shared the same methodological objective of developing a modular Lagrangian drifter capable of holding several sensors and measuring temperature and salinity at different water depths. While some projects (the 
MIDAS series) required the sensors to be as close as possible to the sea surface, others (CANOA, MOC2 and $\mathrm{TIC}-\mathrm{MOC}$ ) tracked the temperature and salinity transformations of water masses at depth, away from the direct influence of the atmosphere.

The series of MIDAS projects had a special international impact, as they were directly linked to the development of the SMOS mission. These projects actually became the largest contribution of Spain to remote sensing research, with Jordi Font as the leader of the ocean salinity part of the mission. Together with the joint USA-Argentine Aquarius mission, SMOS has been an unprecedented strategy to retrieve information on SSS at global scales (Lagerloef and Font 2010). The instruments in both missions exploit the fact that significant information on sea surface dielectric properties (related to salinity) can be retrieved from the ocean microwave emissions, hence providing information of the skin-depth surface salinity (Font et al. 2010).

The Lagrangian work in the framework of the MIDAS projects was mostly of a technological nature. Surface drifters with temperature and salinity sensors gathering data in the uppermost layers of the ocean were designed. The objective was to calibrate remote sensing measurements that were to be obtained with a two-dimensional microwave imaging radiometer using aperture synthesis developed for the SMOS mission. To fill the bridge between the skin depth measured by satellite $(1 \mathrm{~cm}$ penetration depth) and the uppermost reliable measures from Argo profilers (between 5 and $10 \mathrm{~m}$ below the surface), several surface drifters were designed and tested. The challenge of measuring SSS with drifters is exemplified by the fact that only four out of eight of the drifters that measured salinity during the Océan Multidisciplinaire Méso Echelle Programme experiment in 2001 provided good results (Memery et al. 2005). These were the CARIOCA drifters, where a water sample at 2 $\mathrm{m}$ depth was pumped inside the buoy and salinity was measured by an antifouling Sea-Bird MicroCAT cell flushed on an hourly basis to avoid biofouling.

During the COSMOS experiment in 2005, three new types of salinity drifters were compared (Reverdin et al. 2007). The first two types, Pacific Gyre and Metocean models, used a WOCE-SVP configuration, with a $41-\mathrm{cm}$ diameter sphere attached to a drogue centred at a depth of $15 \mathrm{~m}$. These models allowed the salinity to be measured $0.4 \mathrm{~m}$ and $0.7 \mathrm{~m}$ below the surface, with life expectancies of over one year and six months, respectively. The third type, known as Surfact, had a float much smaller than the WOCE-SVP standard and included an unpumped conductivity/temperature cell measuring about $0.2 \mathrm{~m}$ below the sea surface with a life expectancy of three months. More recently, during the French GLOSCAL experiment, similar comparisons between drifters were made (Brion et al. 2010). For this experiment, the Pacific Gyre and Metocean companies instrumented WOCE-SVP drifters with conductivity sensors at a depth of about $0.4 \mathrm{~m}$ and $0.5 \mathrm{~m}$, respectively, and a new light float, called Surplus, measured the salinity at $0.2 \mathrm{~m}$ depth.

In line with these international efforts to provide sea surface and subsurface salinity data, the DOFTICM started to develop the ICM-AKP drifter.

\section{The DOFT-ICM design: ICM-AKP buoy}

The body of the DOFT-ICM design consists of a spherical hull containing the batteries and the electronics of the system with an external connector to communicate with additional sensors (Fig. 5). The electronics has a modular structure, with a system of capacitors designed to minimize the energy expenditure. The sphere's diameter is within the WOCE-SVP standard size range $(30.5-40 \mathrm{~cm})$ and the structure is made of a polypropylene/glass fibre composite, which is impermeable and resistant to both mechanical tension
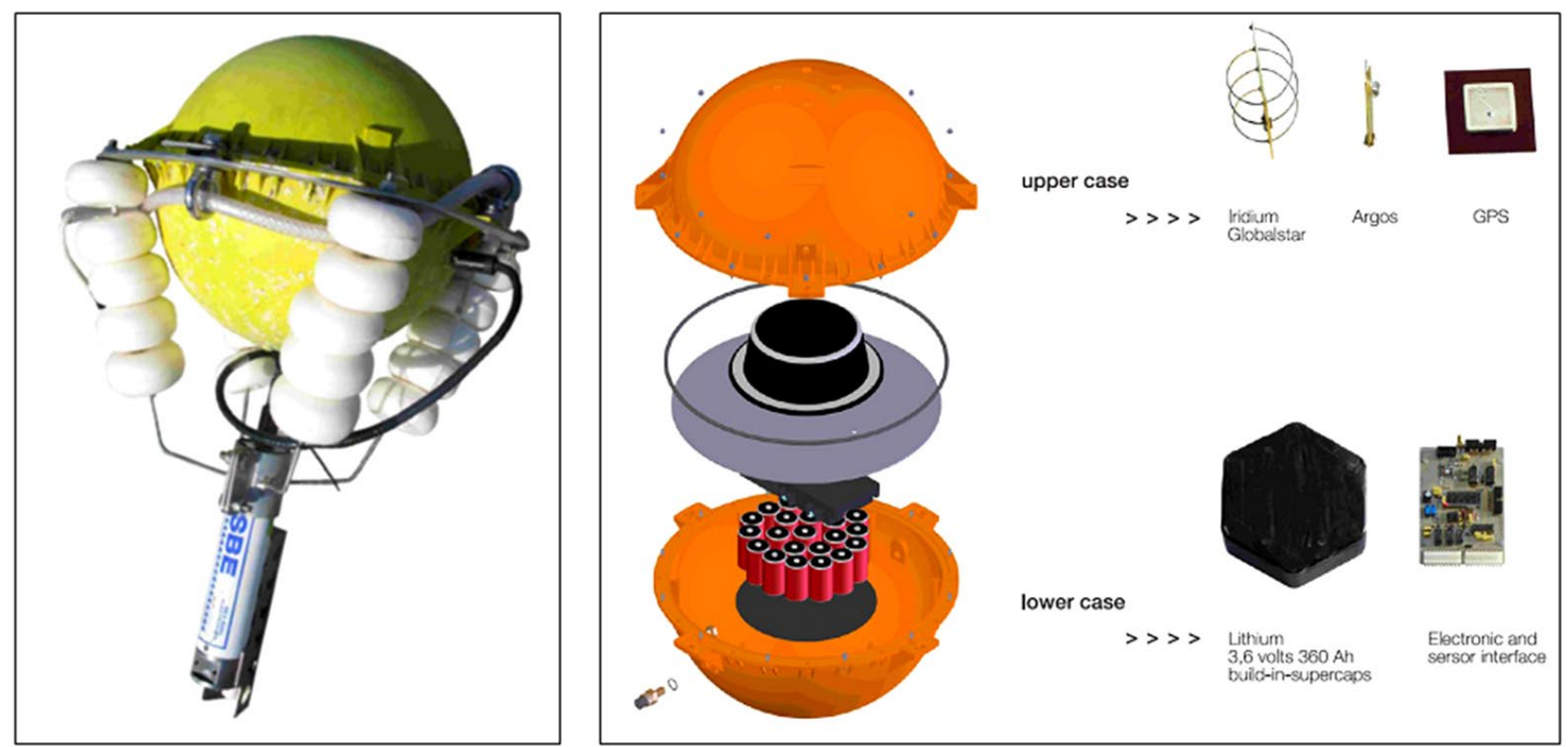

Fig. 5. - Left: the ICM-AKP buoy equipped with a MicroCAT CTD for surface measurements. Right: scheme depicting the internal structure within the sphere. 
Table 1. - Main properties of different telemetry systems. SBD, short bus data.

\begin{tabular}{|c|c|c|c|c|c|}
\hline Name & Localization & Loose path (Mhz/db) & $\mathrm{N}^{\mathrm{o}}$ of satellites & Altitude $(\mathrm{km})$ & SBD Packet System \\
\hline Iridium & GPS & $1600 / 154$ & 66 & 781 & SIMPLEX - 100 bps \\
\hline Globalstar & GPS & $1600 / 154$ & 48 & 1400 & DUPLEX - $2400 \mathrm{bps}$ \\
\hline Orbcomm & GPS & $150 / 134$ & 29 & 775 & DUPLEX - $2400 \mathrm{bps}$ \\
\hline ARGOS & Doppler & $400 / 142.5$ & 6 & 850 & SIMPLEX - 400 bps \\
\hline
\end{tabular}

and insulation. The shell can use up to four watertight connectors, through which sensors communicate with the power supply and memory devices. The signal conditioning circuitry to digitalize sensor signals and the data management software are included in a single printed circuit board (PCB) to facilitate manufacturing and system testing. The core of the PCB has an 8-bit micro-controller with Harvard architecture and a RISC instruction set. The board had wide connectors to facilitate any future expansion. It has the capacity to handle external instruments with RS232 output and converters with up to 24 bits that process the data from the sensors. The transmitter is the ARGOS homologated X-CAT 102 of Seimac Ltd, able to operate at 3 V. The primary power supply is a compact pack of lithium chloride $(\mathrm{LiCl})$ batteries, which provide the highest energy density with currently available technology. The system integrates a set of "super capacitors" to supply the current spikes required by the satellite transmission without degrading the duration of the system. The lifetime of the batteries has been estimated to be longer than two years.

Satellite communications systems may use geostationary and low Earth orbiting satellite networks. For instrumented drifters, in which energy consumption is a limiting factor, it was selected low Earth orbiting networks that have the lowest power requirements per packet of data transmitted. Table 1 discloses the main characteristics of the four constellations of satellite communications currently available: Iridium, Orbcomm, Globalstar and ARGOS. Both Iridium and Orbcomm use bidirectional (half duplex) communication requiring a sophisticated communication protocol and thus involving a higher energy consumption than Globastar and ARGOS. Hence, if the applications do not require bidirectional communications, ARGOS and Globalstar offer a set of advantages in terms of simplicity, reliability and energy consumption. In particular, the energy required per packet for data transmission is between four and ten times smaller. Additionally, in bidirectional systems, the transmitted packets are validated a given number of times that can be configured by the user, making it difficult to estimate the batteries' lifetime.

The units designed to sample the near-surface waters had a special frame which allowed the sensors to be attached at a minimum water depth, which turned out to be about $0.5 \mathrm{~m}$ for the MicroCat probe, and used a standard holey-sock drogue at a typical depth of 15 $m$ with a suitable length and width to meet the WOCESVP requirements. In contrast, the units designed to sample the subsurface waters (typically at $100 \mathrm{~m}$ depth) had external sensors located at the mouth of the drogue, and the rope between the buoy and sensors was replaced by an energy-supply and data transmission ca-
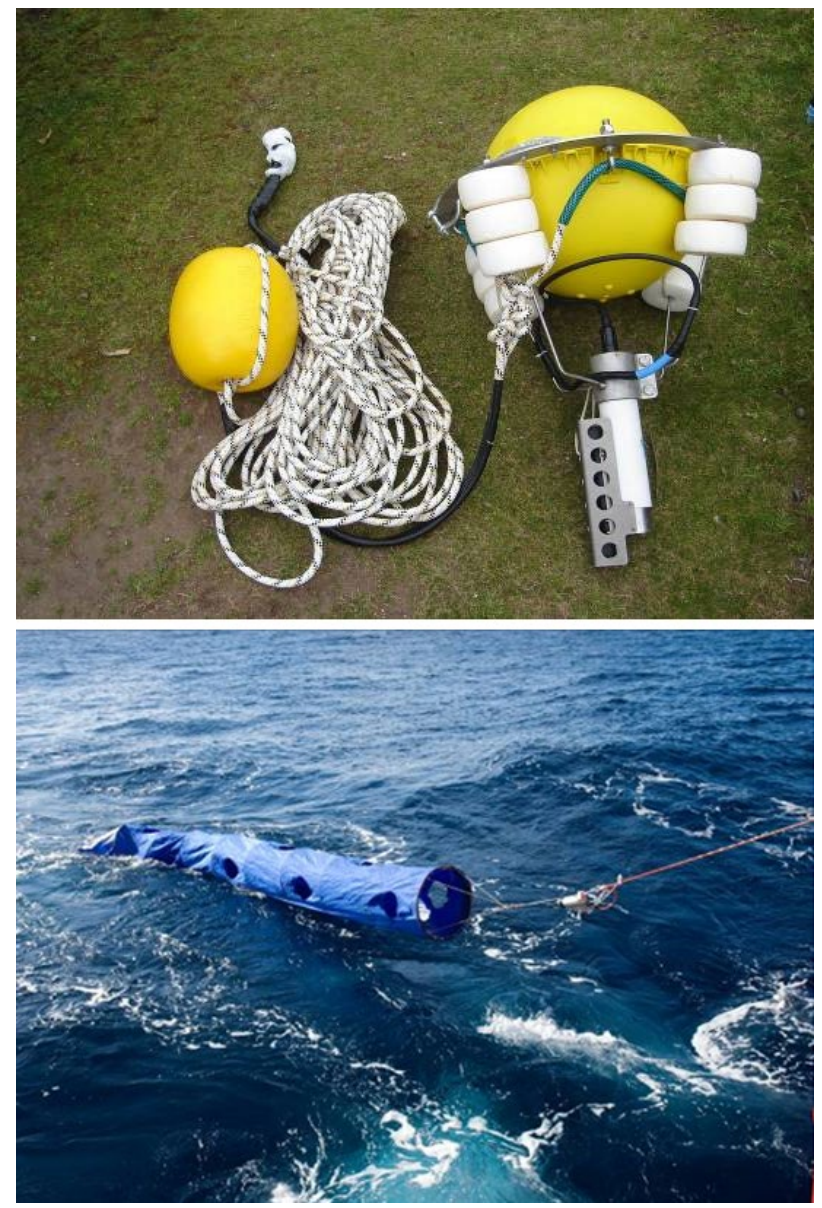

Fig. 6. - Top: drifter configuration with an external probe and tension-connecting elements for sampling at a nominal depth of $0.5 \mathrm{~m}$. The $15-\mathrm{m}$ rope leads to the drogue. Bottom: configuration for subsurface sampling where sensors are located at the mouth of the holey-sock drogue and the rope is replaced by a tension-holding energy and data transmission cable. The picture corresponds to the deployment of a 100-m depth drifter.

ble capable of supporting the tensions between the two elements (Fig. 6). This development implied a substantial redesign of several connectors to sustain the cable tensions. It also required longer and wider holey-sock type drogues to ensure a suitable drag ratio between the drogue and the other components of the buoy system.

During the last decade, over 100 of these buoy systems have been built and deployed in many oceans, and they have also been used in shelf-platform moored systems for continuous monitoring. The cruises on which DOFT-ICM drifters have been deployed include those specifically led by DOFT-ICM researchers at the eastern boundary of the North Atlantic subtropical gyre (CANOA07 and CANOA08 in November 2007 and 2008 respectively), in the western Atlantic equatorial region (MOC2-Ecuatorial in April 2010), in the central region of the North Atlantic subtropical gyre (SPURS 

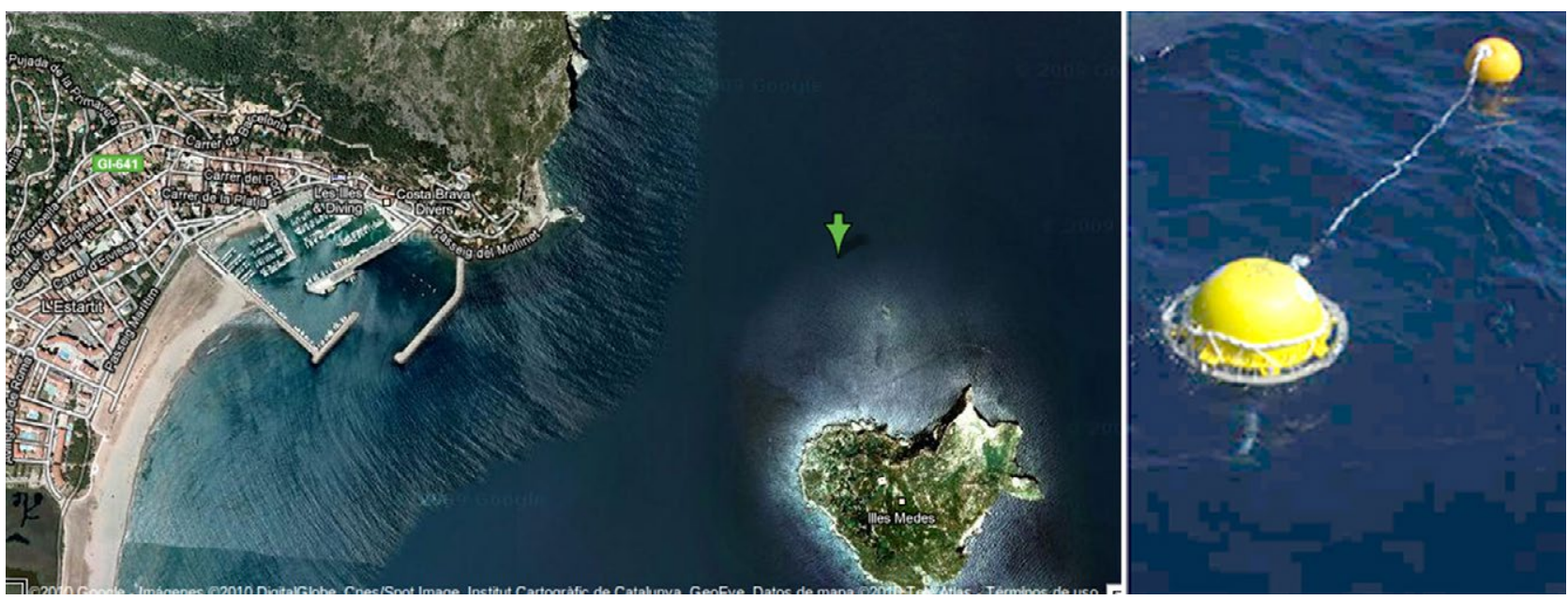

Fig. 7. - Left: first test of the ICM-AKP buoy at Medes Islands (northeast Spain). Right: view of the moored buoy during the testing period.
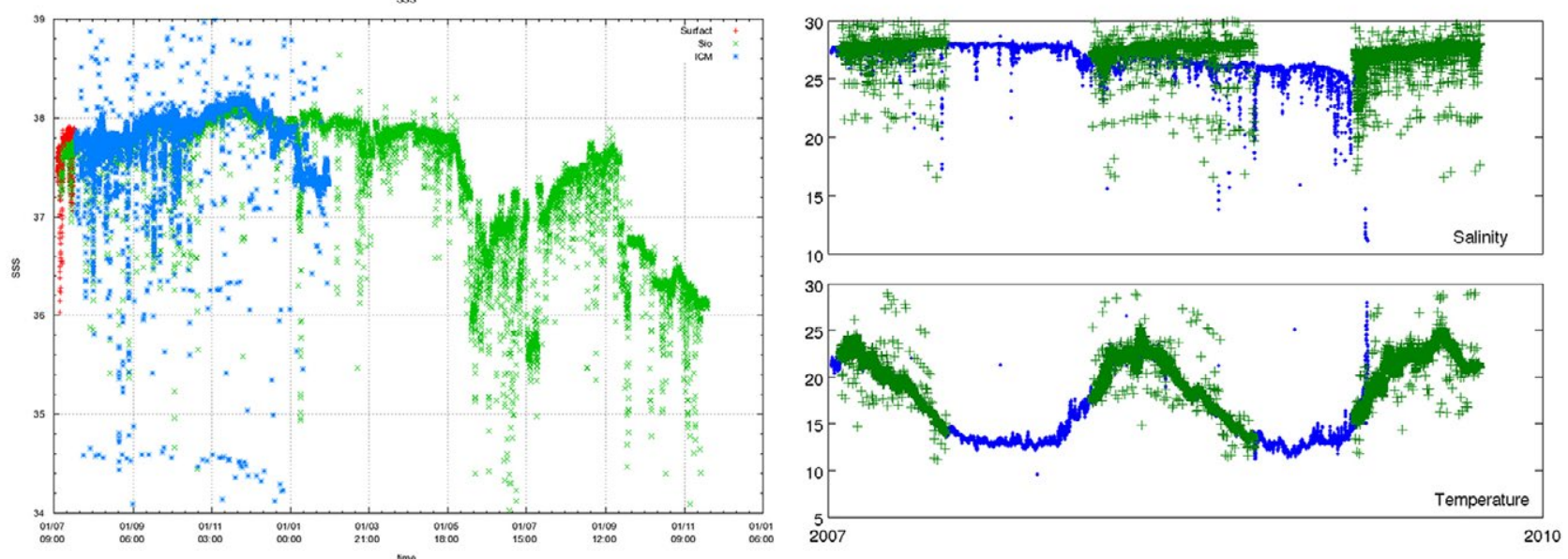

Fig. 8. - Left: salinity time series from three buoys moored at Cape Creus (northeast Spain); Surfact/Metocean (red), ICM-AKP (blue) and SIO/Pacific Gyre (green). Right: time series of temperature and salinity for the entire period 2007-2008.

in April 2013) and in the Brasil-Malvinas Confluence region (TIC-MOC in March 2015). Other units have been used for continuous monitoring at fixed locations, initially tested on the Catalan shelf and later used in moorings off Chile and Mexico in the framework of ongoing international collaborations.

Preliminary in situ tests of data recording and transmission through the ARGOS system were performed between 2007 and 2010 close to the Medes Islands, off the protected area of Cape Creus (Fig. 7). Three buoys were deployed at the site for comparison and performance purposes: a Surfact/Metocean (using a SBE 47 C-T system), a SIO/Pacific Gyre (SBE 37 $\mathrm{C}-\mathrm{T}$ ), and the ICM-AKP buoy. The ICM-AKP buoy was instrumented with a Sea-Bird MicroCAT CTD measuring at $0.4 \mathrm{~m}$ below the surface and providing data of near-surface temperature and salinity. In Figure 8 we have represented the entire time series for these three instruments. The Surfact/Metocean buoy stopped the data transmission less than one month after being moored. The ICM-AKP buoy and the SIO/ Pacific Gyre continued to transmit throughout 2007. Both buoys displayed the same range of daily and low frequency salinity variability between January 2007 and February 2008 (Fig. 7). The low salinity values appear to correspond to fresh water pulses related to precipitation and water discharges of the Ter River, close to the mooring location. A slight shift between the two signals appeared in November but was reduced by the end of the month. The mooring was accidentally released during a storm and the two buoys remained adrift for two months before being recovered on January 30, 2008 (see Fig. 9). After recovery, it was confirmed that the salinity sensor of the SIO/ Pacific Gyre model had degraded much faster than that of the ICM-AKP, apparently because its sensor protection led to a reduced pumping water flow.

Simultaneous with the above developments, the emphasis in the frame of CANOA and subsequent projects was on determining the salinity and temperature under the surface mixed layer, in order to assess the transformations of the water masses as they moved from one region to another below the sea surface mixed layer. Various DOFT-ICM drifters dragged at $100 \mathrm{~m}$ depth were used during the CANOA08 (Peña-Izquierdo et al. 2012) and the MOC2-Equatorial cruises (Claret et al. 2012). In both cruises the probes were placed near the sea surface or at the drogue mouth. The drifters with 

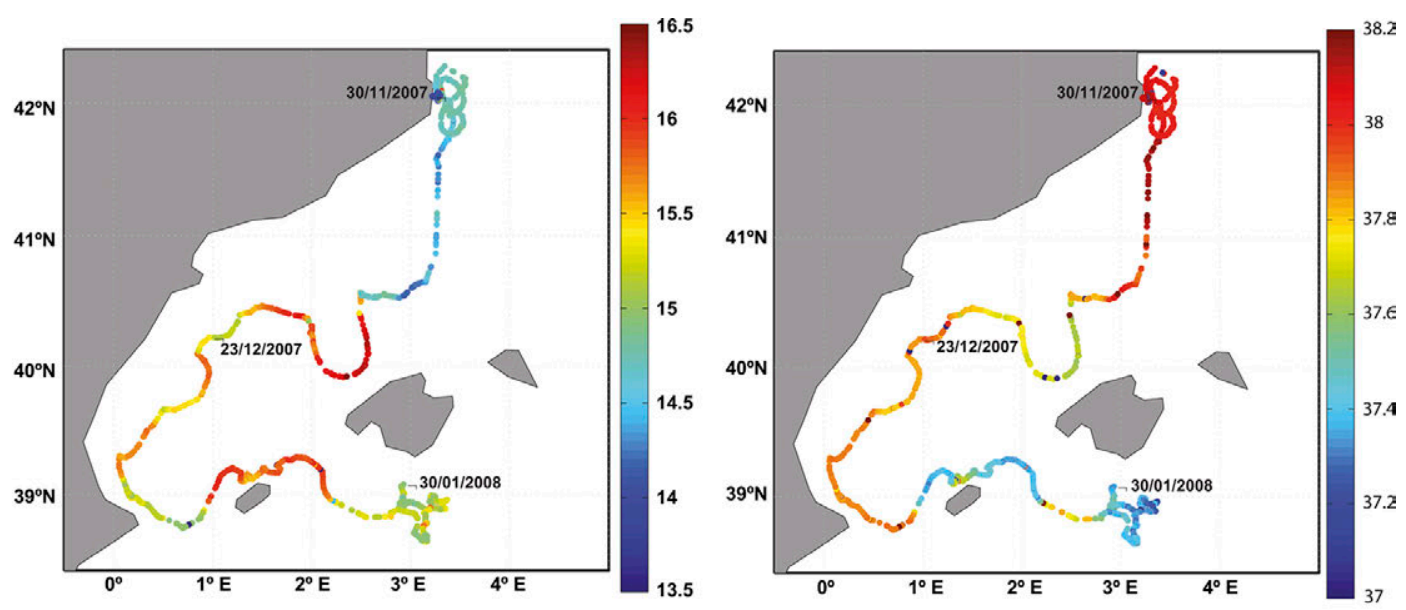

Fig. 9. - Trajectory of the first ICM-AKP prototype measuring sea surface temperature (left) and salinity (right) after being released accidentally from its mooring position.
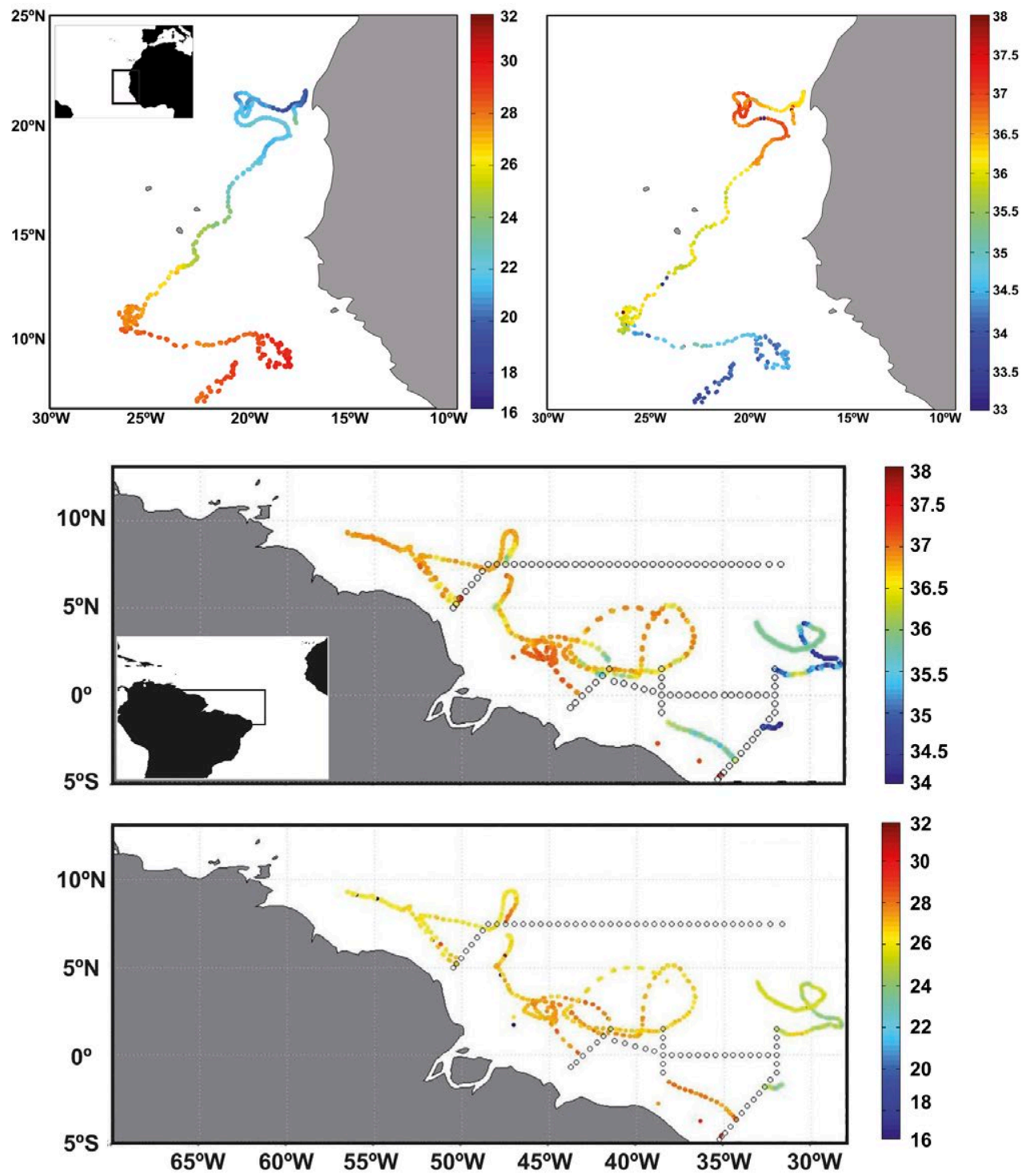

Fig. 10. - Top: trajectory of a subsurface drifter (100-m nominal depth) deployed during the CANOA08 cruise, off NW Africa in November 2008, with colour-coded salinity (right) and temperature (left) measurements. The trajectory started off Cape Blanc and extended between 23 November 2008 and 4 November 2009. Bottom: trajectories of several surface and subsurface drifters dragged at nominal depth of $15 \mathrm{~m}$ (top) and $100 \mathrm{~m}$ (bottom) deployed in the North Brazil region during the MOC2-Equatorial cruise in March 2010; the sea surface salinity and temperature are colour-coded. The round circles are locations of CTD stations during the cruise. 


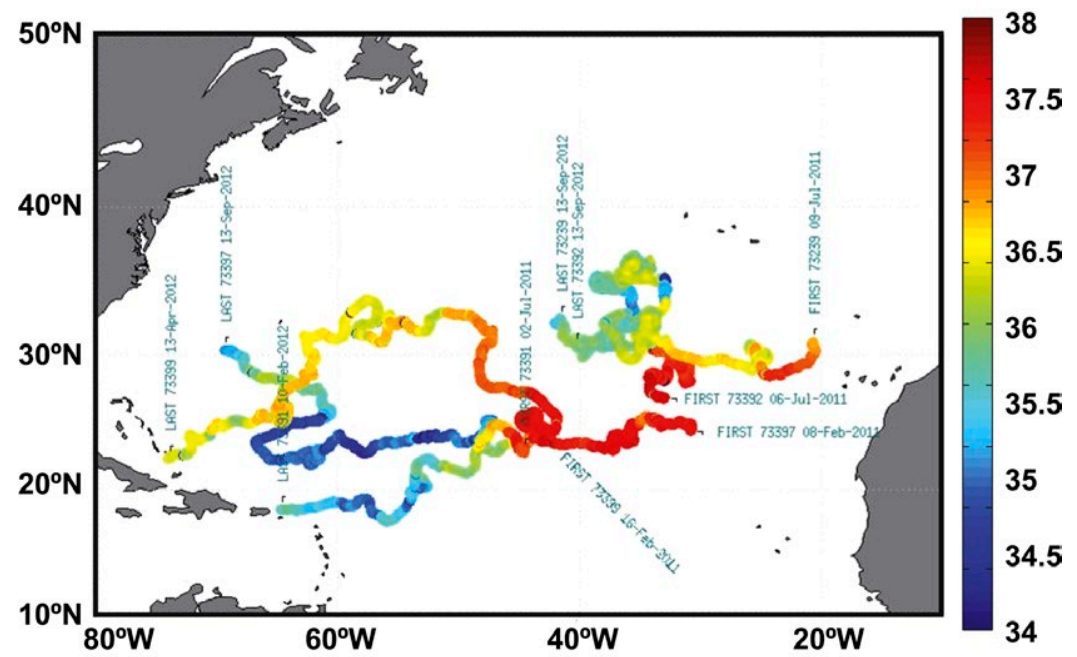

Fig. 11. - An example of surface drifters (nominal depth of $15 \mathrm{~m}$ ) released in the North Atlantic in the framework of international collaborations.

the instruments near the sea surface worked very well, with several units transmitting data for a period longer than one year in both regions (Fig. 10). In contrast, the drifters instrumented at depth, which used the tension and transmitting cable system, did not perform as well, with the longer data transmissions not exceeding a few months. During the MOC2-Equatorial cruise, the use of Globalstar telemetry in several drifters allowed the rate of data gathering and transmission to be changed interactively.

During the Spanish Malaspina oceanic expedition (Duarte 2015) and the SPURS experiment (Reverdin et al. 2015), a total of 20 and 10 surface drifters were deployed, respectively (Fig. 11). In the SPURS experiment, most of the observations were taken in the region of maximum SSS for the North Atlantic Ocean, an area where salinity was expected to be very stable, but the measurements displayed an unexpectedly high variability (Reverdin et al. 2015).

\section{OPERATIONAL OCEANOGRAPHY}

The development of operational oceanography has been a natural step forward to address the complexity of oceanic flows and to improve our ability to predict the future of the ocean state. The impact of operational systems goes far beyond the basic ocean and climate research context. Presently, many downstream services stem from the use of operational systems in terms of marine trade, navigation security, environment marine pollution, fisheries activities, leisure activities and many other new applications.

Assessing and responding efficiently to environmental pollution involving oil spills is clearly one of the areas in which ocean operational systems can provide the necessary tools. Oil spills have produced the most impacting consequences on marine ecosystems (e.g. Ixtoc Oil well, Amoco Cadiz, Castillo de Bellver, Atlantic Empress, Exxon Valdéz). Fortunately, the number of accidents associated with oil spills has been decreasing since the 1980s (see Fig. 2 in, ITOFF 2013) because of technological developments improving the safety of marine trade and to the setup of mandatory agreements, regulations and commitments adopted at international level (SOLAS 1974, EPA 1990, IMO 1993, 2011). However, new regulations are more often adopted as a reaction to large accidents rather than in anticipation of future contingencies.

In the late 1990s and early 2000s, in a time interval of only three years, two impacting accidents occurred in European waters: the Erika accident in 1999, in front of the French coasts, and the Prestige accident in 2002 near Cape Finisterre, off the northwest cost of Spain. The Prestige incident in November 2002 was a key event for the Spanish oceanographic community. The harsh environmental conditions of bad weather and a rough sea, together with a questionable management strategy, led to the most devastating oil pollution event on Spanish coasts (García-Olivares et al. 2011). About $900 \mathrm{~km}$ of shoreline were hit by heavy oil, producing a great impact not only on the marine environment but also from a socio-economic point of view. The tanker spilled oil continuously from the distress call in November 13 and during the offshore towing operations. The tanker finally broke into two parts on November 19, sinking to $3500 \mathrm{~m}$ at $130 \mathrm{~nm}$ from the coast and resulting in a very large spill. The authorities had to fight the first oil reaching the coast while trying to foresee the evolution of the subsequent spills. This was the point at which the oceanographic community, through the coordination of a scientific assessment committee constituted for the accident (http://csicprestige.iim.csic.es/), developed forecast procedures necessary for assessing environmental impacts at the short and long term.

\section{The Prestige accident and the ESEOO project}

The previous experience in Lagrangian measurements led many DOFT-ICM researchers to become involve in the Prestige response actions. The participation focused on deploying drifters and providing an automatic tracking and data delivery system to help the monitoring tasks. The urgency of the situation required the improvisation of a surface drifter by adapting available ARGOS-spheres usually implemented in 


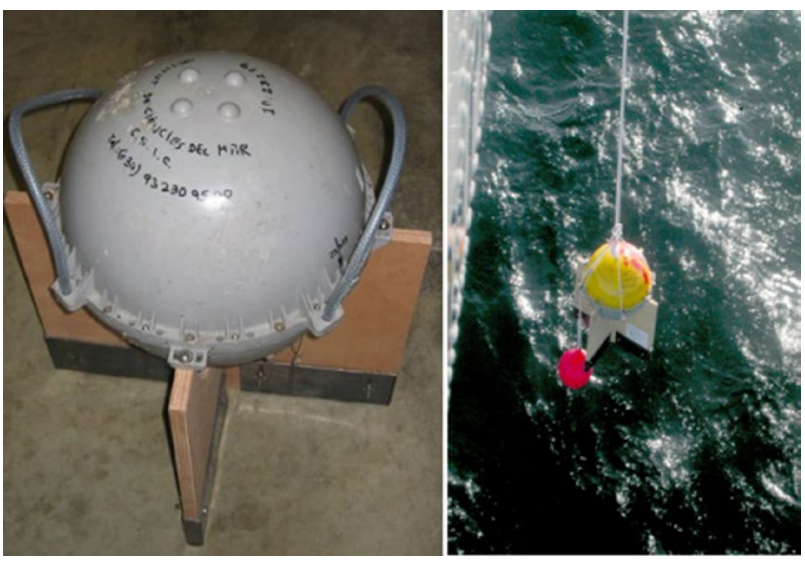

Fig. 12. - Left: CODE-like drifters built during the Prestige tracking activities. Right: drifter deployment from a research vessel in December 2002, a few days after the Prestige accident.

the WOCE-SVP drifters (see Fig. 12). The design was inspired by the CODE-type drifters, in which the typical sails (see for example Fig. 1) were replaced by two plates of wood carrying small pieces of lead as ballast to compensate for the sphere buoyancy. This arrangement diminished the direct effect of wind drag over the sphere while keeping the upper part of the sphere above sea level to allow the normal operation of the transmission system. The ensemble of trajectories of all such drifters during the Prestige crisis is shown in Figure 13. Although a detailed study of the ability of this drifter configuration to track the spills was not made, the first set of four drifters deployed in a spill close to Cape Finisterre $\left(43^{\circ} \mathrm{N}, 9^{\circ} \mathrm{W}\right)$ on December 19 , arrived at the coast at places in the Bay of Biscay (around 3.5-4.5 $5^{\circ} \mathrm{W}$ ) where several spills had been reported just a few hours earlier (Garcia-Ladona et al. 2005).

As a consequence of this accident, the project ESEOO (Establecimiento de un Sistema Español de
Oceanografía Operacional) was launched between 2004 and 2007 with the aim of organizing and coordinating the Spanish oceanographic community towards developing an operational oceanography system capable of dealing with similar future marine pollution events. This project focused on building an operational meteo-ocean forecast system linked to an oil spill dispersion model (Castanedo et al. 2006, Abascal et al. 2009). One of the outcomes was the definition and development of a Technical Unit for Tracking and Prediction (USyP) for coordinating all technical aspects of monitoring and forecasting marine pollution events, and interacting with authorities and the search and rescue services (Sotillo et al. 2008). The operational concept of the USyP was tested in a series of dispersion exercises simulating virtual oil spills using surface drifters as a proxy. Three main exercises were distributed among all the marine Spanish coasts (Baleares-2005, Gijon-2006, Finisterre-2006) in combination with the development of the ESEOO marine forecasting system. This system covered all Spanish territorial waters and remained operational from 2007 to 2013, when it was replaced by the Iberia-Biscay-Ireland Regional Operational System as part of the oceanic component of the European Copernicus system (Sotillo et al. 2015).

Of particular interest was the Finisterre-2006 exercise carried out in November 2006, with the aim of repeating a situation similar to the Prestige incident. Drifters were deployed in two clusters near and far from the coast in front of Cape Finisterre (Fig. 14). The ensemble of trajectories exhibited a similar global behaviour to that of the first set of drifters during the Prestige incident (compare Fig. 14 with Fig. 13). In fact, the weather conditions were quite similar, characterized by strong north easterlies with significant wave heights during the first few days. The drifters initially moved along the coast over the shelf and turned around
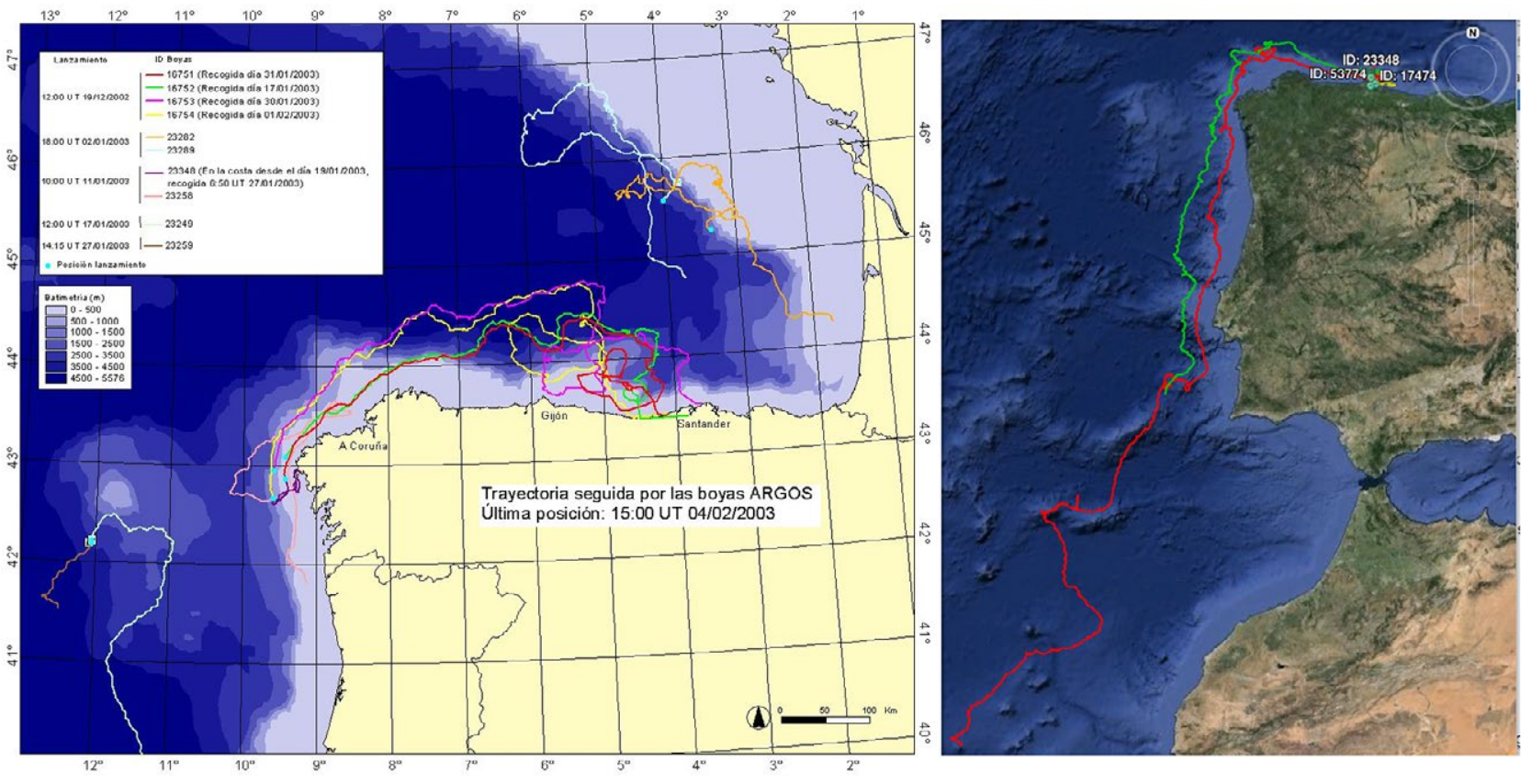

Fig. 13. - Left: trajectories of drifters during the Prestige incident. Right: trajectories during the Gijon-2006 experiment. 


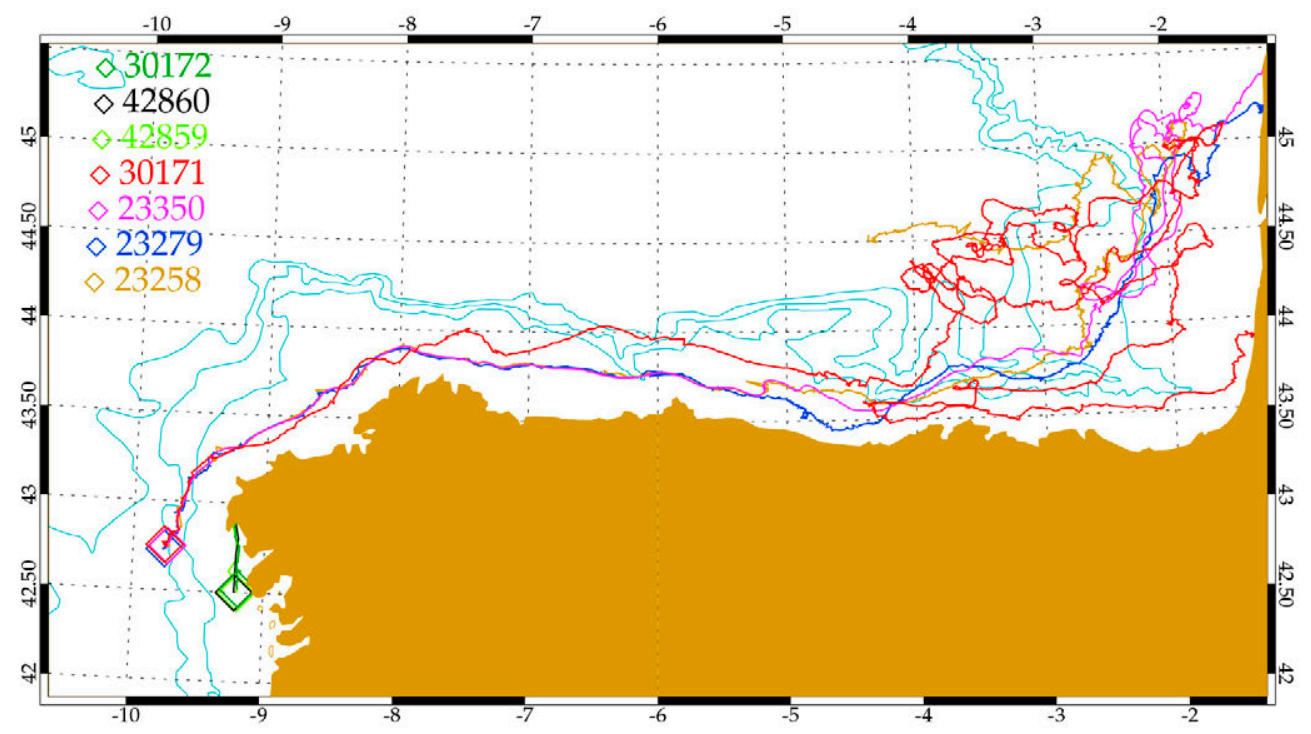

Fig. 14. - Drifter tracks during the Finisterre-2006 experiment.

Cape Finisterre to reach $8^{\circ} \mathrm{W}$. At that longitude, drifters deployed during the Prestige incident detached towards deeper waters and moved slightly north as they progressed irregularly, looping several times before impacting the northern Spanish coast between $4.5^{\circ} \mathrm{E}$ and $3^{\circ} \mathrm{E}$. In contrast, in the 2006 exercise, the drifters remained within the shelf area up to $4^{\circ} \mathrm{E}$, where most of them detached towards deeper areas of the Bay of Biscay before re-entering the shelf zone in the Aquitania region and eventually beaching on the French coast. A short time forecast of the initial evolution using the ESEOO system was unevenly successful at simulating the observed drifter tracks (Fig. 15). The forecast was quite good for the drifters close to the coast but overestimated the drifter displacement for the drifters deployed at the shelf/break area.

These results suggest the existence of recurrent patterns of regional circulation off the northwestern Spanish coast. In particular, the area exhibits a seasonal cycle in which the poleward flow progressing along the shelf is characteristic of the winter season
(Ruiz-Villarreal et al. 2006). In contrast, a southerndominated flow appears in spring and summer associated with the upwelling season along the Spanish-Portuguese coast. This second regime is well illustrated by the trajectories of drifters during the Gijon-2006 experiment (Sotillo et al. 2008). In May 2006, some drifters deployed in the Bay of Biscay around $5-6^{\circ} \mathrm{W}$ progressed west along the coast to Cape Finisterre and turned south, almost reaching the Canary Islands (Fig. 13). The trajectories of two drifters closely followed the shelf/slope along the entire western Iberian margin, reflecting the characteristic southward flow favoured by the spring-summer upwelling situation on the northwestern Spanish-Portuguese coast.

\section{TOSCA project: PK1 drifters}

Partly motivated by the serious consequences of the Prestige incident and accentuated by the disaster of the Deep Water Horizon drill platform in the Gulf of Mexico in 2010 (among the ten largest spills of the his-
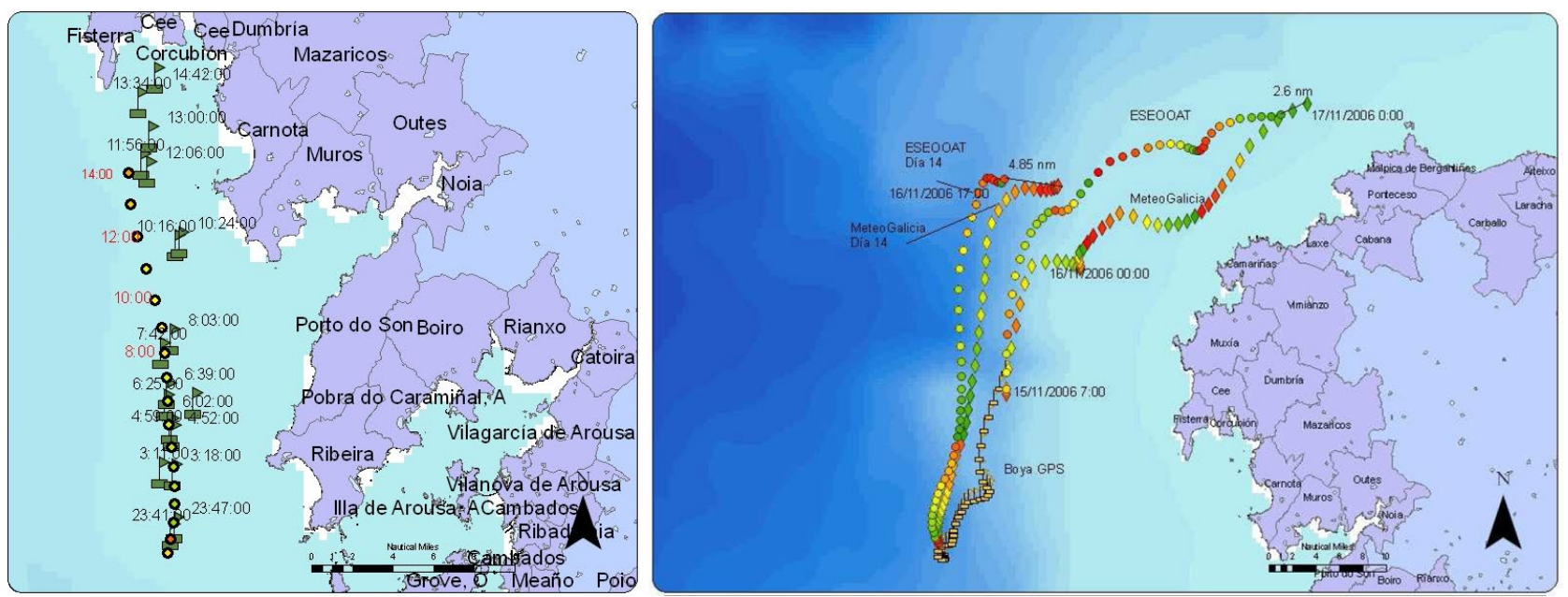

Fig. 15. - ESEOO forecasting for the Finisterre-2006 experiment. Left: Observed (green flags) and simulated (orange filled circles) trajectories for the coastal deployment. Right: Observed (orange flags) and simulated (red, green, yellow and orange circles and diamonds) trajectories for the offshore deployment (Courtesy of Enrique Álvarez Fanjul, Puertos del Estado). 

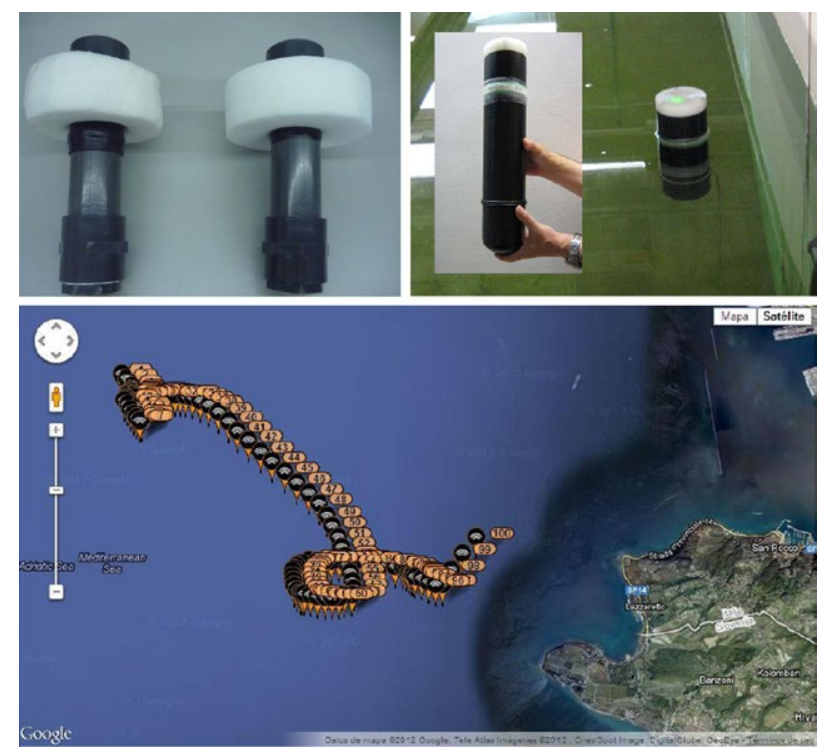

Fig. 16. - Top: first prototype of the PK1 drifter (left) and current design (right). Bottom: trajectory of the first PK1 prototype in deployments in the Gulf of Trieste.

tory), the European Commission explicitly recognized marine pollution and safety among its specific priority research programmes. The Mediterranean Basin, still the shortest route from Asia to Europe and only representing $0.8 \%$ of the area of the world ocean, is a region bearing a great maritime seaborne traffic, with onesixth of the world oil trade crossing the region or arriving at its coasts. DOFT-ICM members were involved in two EU INTEREG projects (TOSCA and MEDESS) with the goal of improving the response and capacity to oil pollution events in the area.

The TOSCA (Tracking Oil Spills and Coastal Awareness) project was more concerned in demonstrating the benefits of innovative observational technologies, such as the combination of coastal radar survey and oil spill drifters to improve forecasting capabilities in marine pollution accidents and search and rescue operations. In particular, within the project, the DOFTICM contributed by proposing a low-cost surface drifter designed to be used for tracking purposes, named PK1. This drifter consists of a small, 43-cm-long cylindrical tube, using common materials and incorporating global positioning system (GPS) telemetry through the Globalstar satellite constellation $(1610-1620 \mathrm{MHz}$ band-L at $1600 \mathrm{~km}$ ). Though the Globalstar constellation does not offer global coverage (it was designed mainly for land uses), it does cover the Mediterranean Basin, the targeted region in the TOSCA project. This system offers two main advantages over other systems: low power consumption, as it carries an emitter of 0.1 $\mathrm{W}$ controlled through a micro-controller (MICROCHIP Inc. $16 f 628$ at $32 \mathrm{Mhz}$ ) and a flat antenna that facilitates the geometrical configuration. Just to compare the differences in energy consumption, the Iridium and Orbcomm systems need $5 \mathrm{~W}$, while the ARGOS system requires $0.7 \mathrm{~W}$. The first prototypes were built using a PVC tube with a ring of polystyrene to mitigate tilting oscillations under rough sea conditions. They were tested during an experiment made in the Gulf of
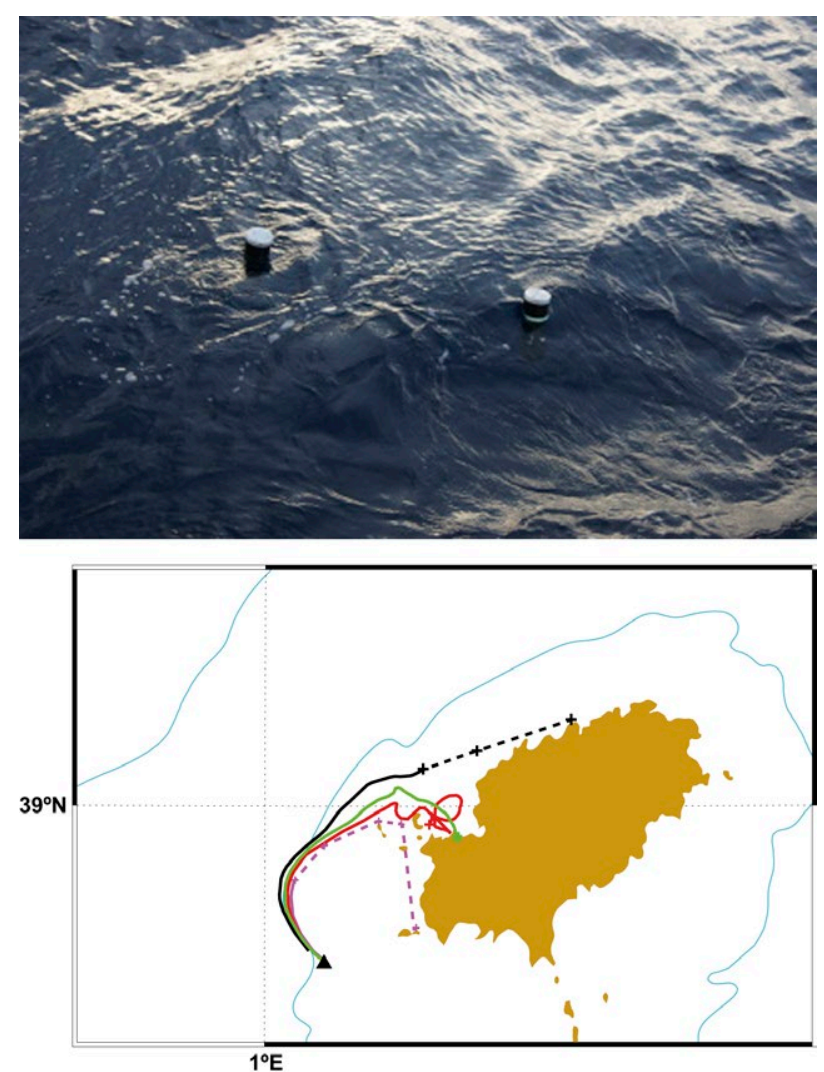

Fig. 17. - PK1 drifters during the TOSCA experiment. Top: a picture of two PK1 units deployed during the experiment. Bottom: trajectories followed by four surface drifters released in the position indicated by the black triangle. In magenta the trajectory followed by the PK1 drifter. Dashed lines are segments of trajectories between irregular positions received due to very bad weather conditions (see the text for details).

Trieste in April 2012 (Fig. 16) and behaved in a similar way to other oil spill surface drifters used in the experiment (Gerin et al. 2012). The original commercial PVC tube $\left(1.4 \mathrm{~g} / \mathrm{cm}^{3}\right)$ of the first prototype was replaced in the final design by a low-density polyethylene tube $\left(0.952 \mathrm{~g} / \mathrm{cm}^{3}\right)$, which provides suitable buoyancy while remaining vertically more stable (Fig. 16).

All these improvements were implemented and tested during a second field experiment in the Ibiza channel in October-November 2012 (Figs 17-19). The goal was to deploy several models of surface buoys in order to validate the ability of operational models to provide suitable forecasts.

The experiment consisted of a ship cruise in which several drifters were released at three points of the Ibiza channel (Fig. 17). The results were partially satisfactory because only some PK1 units provided continuous data recording along their paths. Several showed many important data gaps over long periods due to an inadequate buoyancy adjustment in conjunction with bad sea conditions during the experiment. The buoyancy was reduced to leave emerged only the upper $10-15 \mathrm{~cm}$ of the drifter (Fig. 17). As a result, wave-enhanced tilting and pitching motions, amplified due to bad weather conditions, prevented correct satellite transmissions and led to random gaps of data. Despite these difficulties in getting continuous data, the TOSCA experi- 


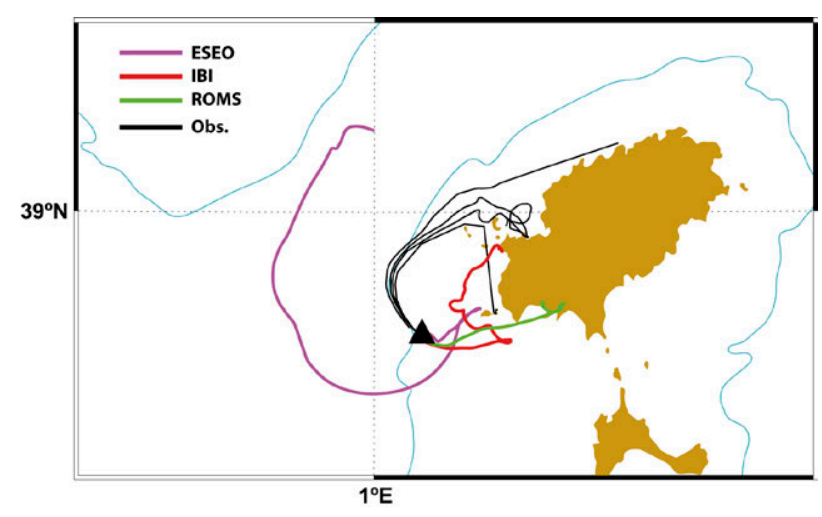

Fig. 18. - Observed versus simulated trajectories with three operational systems. Black lines are drifter trajectories during the TOSCA experiment. The coloured lines are the trajectories simulated by three operational models. ESEO refers to the operational system issued from the ESEOO Spanish project covering the western Mediterranean Basin (Sotillo et al. 2015). IBI refers to the IBI-MyOcean system from Copernicus services that cover half the western Mediterranean Basin. ROMS refers to the SOCIB operational system (Sotillo et al. 2008). Trajectories were computed using a Lagrangian model considering only advection by ocean currents and a wind drag term with a drag coefficient of $1.5 \%$.

ment proved the low-energy consumption of the PK1 System: all drifters were programmed to emit at a high transmission rate (every $30 \mathrm{~min}$ ) and some of them lasted 5 months before dying definitively.

Particularly interesting were the tracks of the first deployment shown in Figure 17, in which a reasonably continuous tracking was possible due to good weather conditions at the deployment time. Four drifters, a PK1 (pink line) and three other surface drifters from different manufacturers were simultaneously deployed. Their trajectories were almost identical as they moved northeastward, turning towards the north of Ibiza Island. One day later, in response to a northern strong wind, the drifters separated, with one progressing along the north of Ibiza, two others beaching on the coast of Ibiza and the PK1 moving southwards until it was trapped at Es Vedrà, an islet located on the southwestern corner of Ibiza Island. The trajectories were simulated with three ocean operational models and using observed winds from a nearby meteo-ocean buoy
(Fig. 17). The results clearly show that the models failed to reproduce the observations and provided different solutions, mainly because they were unable to capture the initial conditions in the area.

In the same experiment, two PK1s were also used to track search and rescue (SAR) targets. These units were attached to two targets: a dummy configured in vertical position and one attached to a live raft and a fender (Fig. 19). These units were arranged with buoyancy similar to the prototypes used in the Trieste experiments but with no additional rings to control vertical stability. In this case the transmissions were quite continuous (every $30 \mathrm{~min}$ ) and did not fail at all except for a short gap in the raft trajectory. The targets veer from north to east and then to south consistent with the wind direction variability during this period. The signal of the drifter attached to the live raft was interrupted for half a day and restarted later. Apparently, because of bad weather conditions, the raft was filled with water and sank, probably forcing the drifter to also be submerged until the attaching rope broke. The drifter returned to the surface only attached to the fender, as was observed from a SAR aircraft two days later; it continued to drift, turning southwards and being finally recovered close to the coast (Fig. 19). In contrast, the dummy (red trajectory in Figure 19) behaved differently from the beginning. Initially it deflected to the right of the wind and then made some loops. Its trajectory was highly correlated with the path of another CODE drifter deployed simultaneously (not shown) at the same location. Though it was more exposed to wind slippage, the vertical configuration of the dummy (with most of the body submerged) had a similar dragging effect as the sails of a CODE drifter. The dummy was finally recovered two days later, after being quickly detected by a SAR aircraft.

This SAR exercise was quite successful and has allowed a direct collaboration to be established with the Spanish SAR Service (SASEMAR). PK1 drifters are being used to test operational systems through similar SAR exercises as in the TOSCA experiment. As an example, a dummy attached to a PK1 and deployed within a filamentary structure of Atlantic cold waters
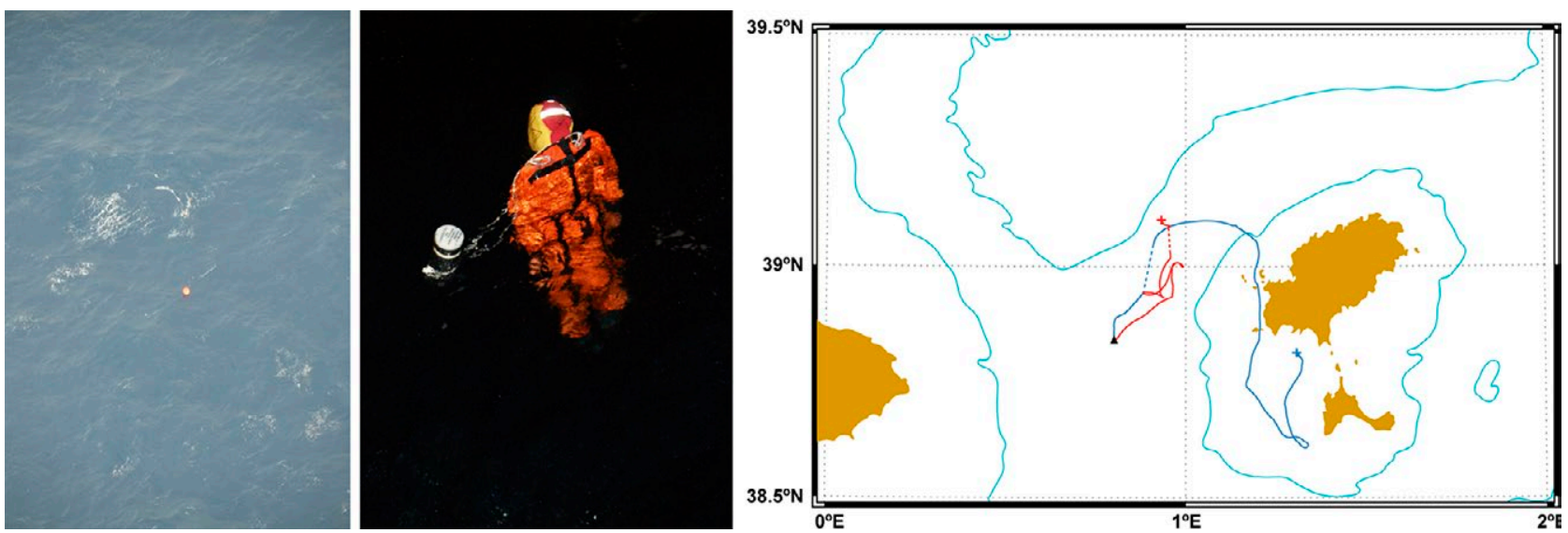

Fig. 19. - Left: dummy in vertical configuration attached to a PK1 drifter during the search and rescue exercise in the TOSCA experiment. Centre: the fender attached to a PK1 as it was visually observed from a SAR aircraft after losing the live raft. Right: trajectories followed by the dummy (red line) and the live raft (black line); the black triangle indicates the deployment position and crosses indicate the recovery locations. 


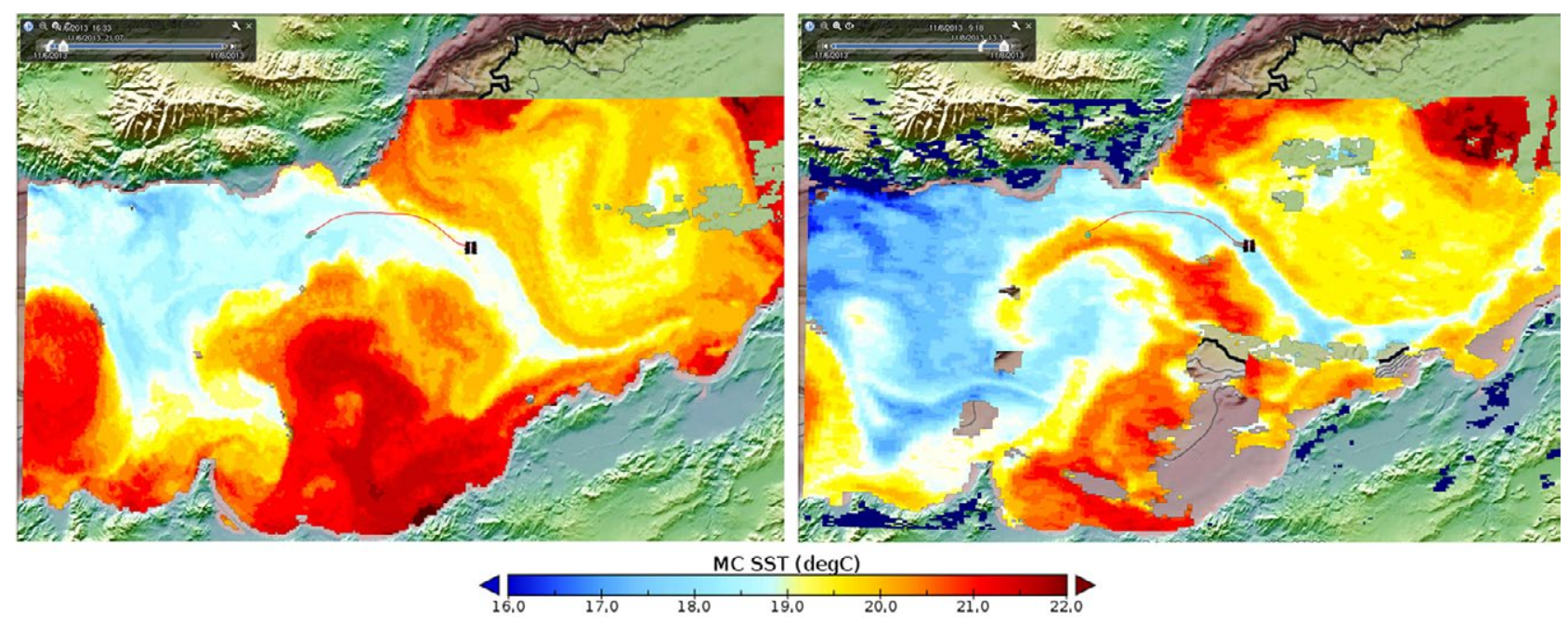

Fig. 20. - Path followed by a dummy tracked with a PK1 deployed close to Cape Gata (Southern coast of Spain, $36.25^{\circ} \mathrm{N} 2^{\circ} \mathrm{W}$ ) in the Alboran Sea, superimposed on infrared SST images. The red line corresponds to the full path between 6 and 10 November 2013, before recovery. The sequence of small circles represents the positions of the dummy six hours around the SST image time. On the left, the initial drift superimposed on the SST image of 6 November 2013 at 13:38 h; the right panel corresponds to the final positions with the SST image of 10 November 2013 at 12:07 h.

in front of the Almeria Bay (Alboran Sea, southern Spanish coast) in November 2013 was advected along the Almeria-Oran front towards the African coast, following the tongue of Atlantic cold waters (Fig. 20). Additionally, the robustness of the PK1 drifter was also tested during these exercises, with successful deployments directly from helicopters at $100 \mathrm{~m}$ height.

\section{MONITORING THE ARCTIC ICE: THE SATICE BUOY}

To end with the latest Lagrangian developments, it is worth mentioning the design of the SATICE buoys, used to track and monitor the ice characteristics and motions in the Arctic region (Fig. 21). These efforts are part of an EU-funded international collaboration to design, build, deploy, and operate a geodetic-quality global positioning system instrument capable of collecting continuous high-precision GPS data while drifting on Arctic sea ice (Elosegui et al. 2012). SATICE buoys provide position coordinates and have brought high-precision geodesy measurements to the Arctic Ocean. These unique observations are being used to gain insight into the response of sea ice and the upper ocean layer to winds and ocean currents over a wide range of timescales, from a few seconds to a few years, and over a wide range of spatial scales, from $100 \mathrm{~m}$ to pan-Arctic scales. The outcome has been the creation of an extensive dataset for the Chukchi and Beaufort Seas during the period 2011-2014 (Fig. 22).

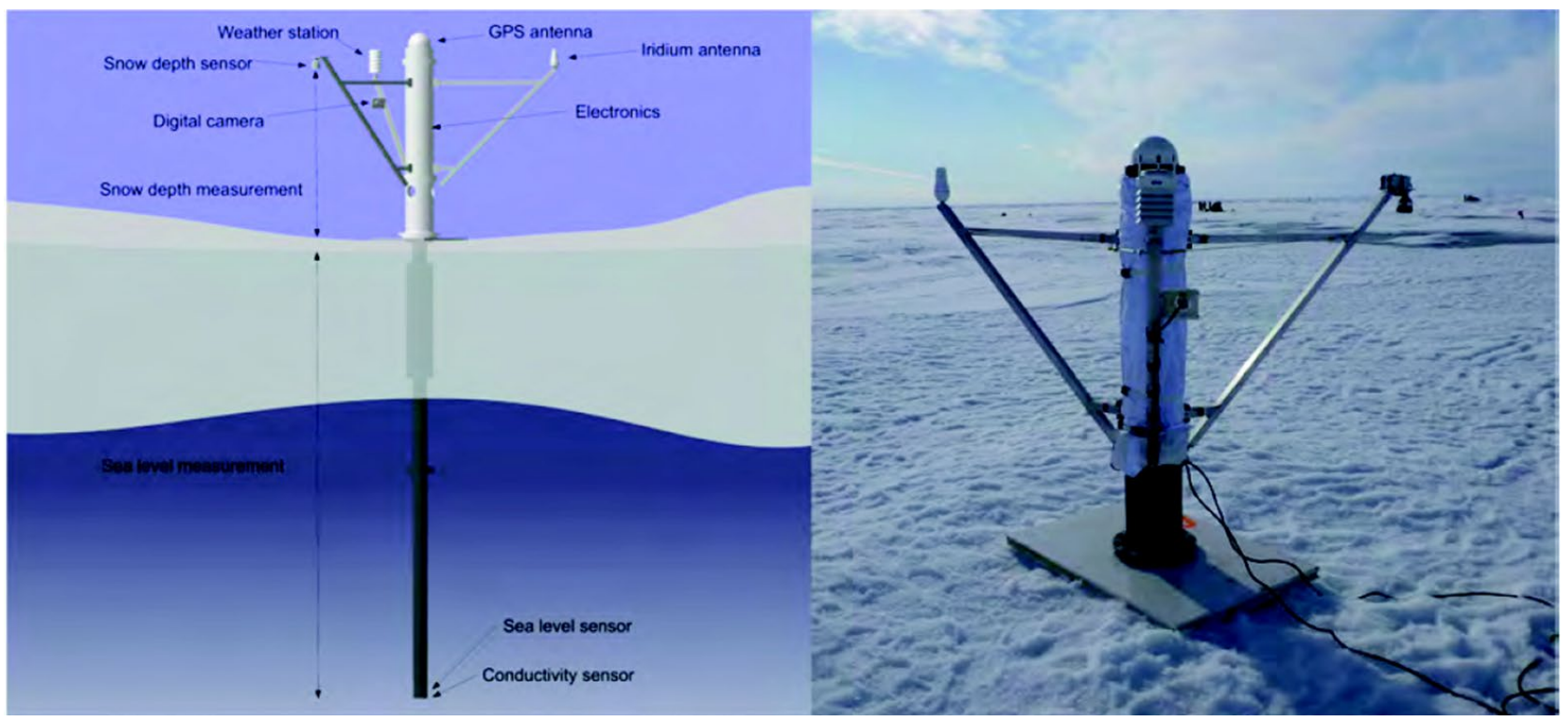

Fig. 21. - Left: scheme of a SATICE buoy, with the key sensors and structure for monitoring atmosphere, snow and sea ice parameters including the upper ocean; the total length of the buoy is approximately $5 \mathrm{~m}$. Right: a picture of a SATICE buoy SI05 (Fig. 2) deployed in the Beaufort Sea in summer 2014 and still operational in July 2015. GPS and auxiliary data from these buoys are downloaded in near-real time through an Iridium data link. 


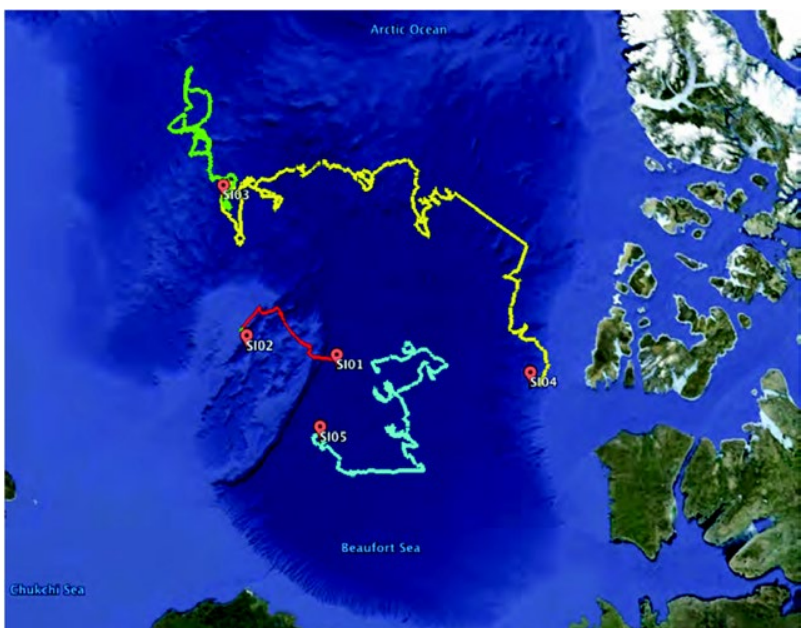

Fig. 22. - Ocean tracks of the sea-ice drifting geodetic-quality SATICE buoys collecting data on the Arctic Ocean since 2011. While operational, the buoys collected dual-frequency carrier-phase observations once every $10 \mathrm{~s}$ for approximately one month in summer 2011 (SI02, red), two months in summer 2011 (SI02, red) and five months in summer-autumn 2012 (SI03; green). Buoys SI04 (yellow) and SI05 (blue) were deployed in summer 2012 and 2014, respectively, and were still operational in July 2015. Between summer 2012 and summer 2015, SI04 travelled more than $6000 \mathrm{~km}$.

The core sensor of the SATICE buoy is a geodeticquality GPS receiving system that provides continuous $(0.1 \mathrm{~Hz})$ three-dimensional position estimates with $\mathrm{cm}$-level precision in a well-defined geodetic reference framework (Elosegui et al. 2012). When deployed, the buoy mechanical structure remains freeze-locked to sea ice, thus responding to wind, ice and ocean dynamics. In addition to high-quality GPS, the dataset also includes auxiliary meteorological, ice, and upper ocean observations (Fig. 21). An additional GPS dataset will be collected Arctic-wide between 2015 and 2017, as part of the EU-funded ICE-ARC programme. Preliminary studies performed using these datasets have already led to significant progress in understanding the response of sea ice to external forcings over time scales ranging from hours to months (e.g. Hwang et al. 2015), and the potential for determining sea surface heights and addressing upper ocean dynamics processes such as freshwater accumulation (e.g. Elosegui et al. 2012). Preliminary processing of this dataset reveals the richness of ice motions, in response to a variety of interconnected processes and forcings, including winds, ocean currents, ice melt and freeze, melt pond formation and draining, snow loading, atmospheric loading, ocean tides, geoid gradients and freshwater storage.

\section{OUTLINE}

This paper reviews the contributions of the DOFTICM in the past 30 years associated with Lagrangian buoy technological developments. The first studies were on mesoscale variability in the Mediterranean, using a few units of radio tracked drifters. In these studies the Lagrangian surface measurements played the role of a complementary technology to assist classical ship surveys of vertical properties of seawater. The advent of the ARGOS satellite system facilitated the track- ing of massive deployments of drifters. This, together with the setup of the European funding programmes in marine sciences in the 1990s, led the DOFT-ICM to organize and participate in more ambitious experiments. A series of cruises focused on the Algerian Basin, where Lagrangian observations were essential to characterize the mesoscale variability and detailed properties of Algerian eddies.

Between 1980 and 2000, the Lagrangian studies of the DOFT-ICM were mainly carried out using drifters from private manufacturers. The Prestige accident in 2002 was the turning point at which DOFT-ICM technicians started to fully build their own prototypes. A CODE-like drifter was rapidly designed to promptly respond to the need to track oil spills during the Prestige incident. Participation in operational activities in subsequent projects eventually led to the development of the ICM-PK1 prototype, a robust and low-cost surface drifter in terms of both energy consumption and transmission costs, that has become a suitable tool for tracking in pollution events and SAR operations.

In 2007, in the framework of the MIDAS-4 and CANOA projects, the DOFT-ICM developed the ICM-AKP, a modular, energetically-efficient and dependable drifter designed to host several sensors. Other suitable properties are a flexible configuration to accept several satellite telemetry networks and a longlasting energy source, with an estimated life span of over two years. Its initial applications have been Lagrangian measurements of temperature and salinity at different depths. The development of a configuration that measures salinity as shallow as $0.4 \mathrm{~m}$ as a proxy of SSS provided an outstanding application. It was aimed at validating and calibrating the measurements inferred from the radiometer onboard the SMOS satellite, necessary because of the limitations of the Argo profiling floats to provide near-surface salinity data. Another application has measured subsurface temperature and salinity, typically at $100 \mathrm{~m}$, to track the path and transformations of waters away from the direct influence of the atmosphere in the Atlantic Ocean. This application required the design of a traction system capable of sustaining larger tensions, transmitting data and supplying energy at this depth.

This long tradition of developing Lagrangian devices has a promising and interesting continuation with the SATICE buoys. Such buoys have started to be deployed in the Arctic to monitor ice characteristics and they are providing important information on the processes affecting the ice structure and its evolution in a key region to understand how climate change affects our environment.

\section{ACKNOWLEDGEMENTS}

The work described in this paper was carried out in the framework of many research projects, which are gratefully acknowledged. These include MIDAS-4 (ESP2005-06823-C05-1), MIDAS-5 (ESP200765667-C04-1), MIDAS-6 (AYA2010-22062-C05-01), CANOA (CTM2005-00444/MAR), MOC-2 (CTM2008-06438-C02-01), TIC-MOC (CTM2011- 
28867), the Malaspina project (CSD2008-00077) and project ACI2009-0977 of the Spanish National Programme of Internationalization of R+D. E. García-Ladona, J. Salvador, P. Fernández and J.A. Jiménez wish to thank the TOSCA (G-MED09-425) and MEDESS4MS (MED 2S-MED11-01) projects (INTERREG-IV MED programme) for funding many activities related to the ICM-PK1 drifter development; J. A. Jiménez was under contract by both projects. Financial support from the Fundación General CSIC (Programa ComFuturo) is acknowledged. The authors wish to thank an anonymous reviewer for helping to improve the quality of the manuscript. Figures with material from already published works are included with author's permission.

\section{REFERENCES}

Abascal A., Castanedo S., Mendez F., et al. 2009. Calibration of a Lagrangian Transport Model Using Drifting Buoys Deployed during the Prestige Oil Spill. J. Coast. Res. 25: 80-90. http://dx.doi.org/10.2112/07-0849.1

Abbott M., Brink K., Booth C.R., et al. 1995. Scales of variability of bio-optical properties as observed from near-surface drifters. J. Geophys. Res. 100(C7): 13345-13367. http://dx.doi.org/10.1029/94JC02457

Benzohra M., Millot C. 1995. Hydrodynamics of an open sea Algerian eddy. Deep-Sea Res. Part I: Oceanographic Research Papers, 42: 1831-1847. http://dx.doi.org/10.1016/0967-0637(95)00046-9

Bitterman D., Hansen D. 1993. Evaluation of sea surface temperature measurements from drifting buoys. J. Atmos. Oceanic Technol. 10: 88-96.

http://dx.doi.org/10.1175/1520-0426(1993)010<0088:EOSST $\mathrm{M}>2.0 . \mathrm{CO} ; 2$

Brion E., Gaillard F., de la Villeon L.P., et al. 2010. GLOSCAL: In-situ datasets and gridded fields for calibration and validation of SMOS. In: Proceedings of ESA-Living Planet Symposium. ESA publications. ESA SP-686. ISBN 978-92-9221-250-6

Camps A., Font J., Vall-llossera M., et al. 2004. The WISE 2000 and 2001 field experiments in support of the SMOS mission: sea surface 1-band brightness temperature observations and their application to sea surface salinity retrieval. IEEE Trans. Gesosci. Remote Sens. 42(4): 804-823.

Castanedo S., Medina R., Losada I., et al. 2006. The prestige oil spill in Cantabria (Bay of Biscay). Part I: Operational forecasting system for quick response, risk assessment and protection of natural resources. J. Coast. Res. 22: 1474-1489. http://dx.doi.org/10.2112/04-0364.1

Claret M., Rodríguez R., Pelegrí J.L. 2012. Salinity intrusion and convective mixing in the Atlantic Equatorial Undercurrent. Sci. Mar. 76S1: 117-129. http://dx.doi.org/10.3989/scimar.03611.19B

Davis R. 1985a. Drifter observations of coastal surface currents during CODE: The Method and the Descriptive View. J. Geophys. Res. 90(C3): 4741-4755. http://dx.doi.org/10.1029/JC090iC03p04741

Davis R. 1985b. Drifter observations of coastal surface currents during CODE: The Statistical and Dynamical views. J. Geophys. Res. 90(C3): 4756-4772. http://dx.doi.org/10.1029/JC090iC03p04756

Davis R., Sherman J., Dufour J. 2001. Profiling ALACEs and other advances in autonomous subsurface floats. J. Atmos. Oceanic Technol. 18: 982-993.

http://dx.doi.org/10.1175/1520-0426(2001)018<0982: PAAOAI>2.0.CO;2

Duarte C. 2015. Seafaring in the 21St Century: The Malaspina 2010 Circumnavigation Expedition. Limnol. Oceanogr. Bull. 24: 11-14. http://dx.doi.org/10.1002/lob.10008

Elosegui P., Wilkinson J., Olsson M., et al. 2012. High-precision GPS autonomous platforms for sea ice dynamics and physical oceanography. In: AGU Fall Meeting Abstracts, pp. C13E-0662.15

EPA. 1990. United States Environmental Protection Agency: Oil pollution act. Available at http://www.epa.gov/oem/content/lawsregs/opaover.htm

Font J., Salat J., Wang D. 1988. Lagrangian and Eulerian observation of inertial oscillations in the shelf break offshore the Ebro River Delta (Catalan Sea, NW Mediterranean). Rapp. Comm. Iint. Mer Médit. 31: 2.

Font J., Millot C., Salas J., et al. 1998. The drift of modified Atlantic water from the Alboran Sea to the Eastern Mediterranean. Sci. Mar. 62: 211-216. http://dx.doi.org/10.3989/scimar.1998.62n3211

Font J., Gabarró C., Julià A., et al. 2003. Oceanographic conditions during the wind and salinity experiment 2000 and 2001, NW Mediterranean Sea. In: Wursteisen P., Fletcher P. (eds), SP525- EuroSTARRS, WISE, LOSAC Campaigns. Ed.. ESA Publications Division, 51-59. UNIV./INST./ORG: ESTECISBN: 92-9092-835-2. ISSN: 0379-6566.

Font J., Camps A., Borges A., et al. 2010. SMOS: The challenging measurement of sea surface salinity from space. In: Proceedings of the IEEE, volume 98 (5): 649-665. Institute of Electrical and Electronics Engineers (IEEE). ISSN: 0018-9219. http://dx.doi.org/10.1109/JPROC.2009.2033096

Gabarró C., Vall-llosera M., Font J., et al. 2004. Determination of sea surface salinity and wind speed by L-band microwave radiometry from a fixed platform. Int. J. Remote Sens. 25: 111-128. http://dx.doi.org/10.1080/0143116031000115175

García-Ladona E., Font J., Del Río E., et al. 2005. The use of surface drifting floats in the monitoring of oil spills. The Prestige case. In: Proceedings of the 19 Biennial International Oil Spill Conference (IOSC), Miami, CD-ROM: 14718A.

García-Olivares A., de Pablos J., Madrigal R. 2011. Sailing the Prestige out to sea. An independent analysis. Sci. Mar. 75: 533-548. http://dx.doi.org/10.3989/scimar.2011.75n3533

Gerin R., Poulain P.-M., Bussani A., et al. 2012. First TOSCA drifter experiment in the Gulf of Trieste (april 2012). Technical report, Instituto Nazionale di Oceanografia e di Geofisica Sperimentale. REL. OGS 2012/91 OCE 6 SIRE, Trieste, Italy, 32 pp.

Hansen D., Herman A. 1989. Temporal sampling requirements for surface drifting buoys in the Tropical Pacific. J. Atmos. Oceanic Technol. 6: 599-607.

http://dx.doi.org/10.1175/1520-0426(1989)006<0599:TSRFSD $>2.0 . \mathrm{CO} ; 2$

Hansen D., Poulain P.-M. 1996. Quality control and interpolations of WOCE-TOGA drifter data. J. Atmos. Oceanic Technol. 13: 900-909.

http://dx.doi.org/10.1175/1520-0426(1996)013<0900:QCAIO W>2.0.CO;2

Hwang B., Elosegui P., Wilkinson J. 2015. Small-scale deformation of an Arctic sea ice flow detected by GPF and satellite imagery. Deep-Sea Res. Part II 120: 3-20. http://dx.doi.org/10.1016/j.dsr2.2015.01.007

IMO. 1993. ISM-CODE: International Safety Management code. International Maritime Organization. Available at: http://www.imo.org/OurWork/HumanElement/SafetyManagement/Pages/ISMCode.aspx

IMO. 2011. MARPOL (Consolidated Edition 2011). International Maritime Organization.

Isern-Fontanet J., Font J., García-Ladona E., et al. 2004. Spatial structure of anticyclonic eddies in the Algerian basin (Mediterranean Sea) analyzed using the Okubo-Weiss parameter. DeepSea Res. Part II 51: 3009-3028. http://dx.doi.org/10.1016/j.dsr2.2004.09.013

ITOPF. 2013. Oil tanker spill statistics. The International Tanker Owners Pollution Federation Limited. Available at: http://www.itopf.com/information\%2Dservices/publications/ documents/OilSpillstats2013.pdf

Lagerloef G., Font J. 2010. SMOS and Aquarius/SAC-D missions: The Era of Spaceborne Salinity Measurements is about to begin. In: Barale V., Gower J., Alberotanza L. (eds). Oceanography from Space. Springer Science+Business Media B.V. pp. 35-58. http://dx.doi.org/10.1007/978-90-481-8681-5

Lumpkin R., Pazos M. 2007. Measuring surface currents with surface velocity program drifters: the instrument, its data, and some recent results. In: Griffa A., Kirwan Jr. A.D., Mariano A.K., et al. (eds). Lagrangian Analysis and Predictions of Coastal and Ocean Dynamics. Cambridge University Press., pp. 39-67. http://dx.doi.org/10.1017/CBO9780511535901.003

McPhaden M., Freitag H., Shepherd A. 1990. Moored salinity time series measurements at $0^{\circ}-140^{\circ}$. J. Atmos. Oceanic Technol. 7: 568-575.

http://dx.doi.org/10.1175/1520-0426(1990)007<0568:MSTSM $\mathrm{A}>2.0 . \mathrm{CO} ; 2$ 
Millot C. 1991. Mesoscale and seasonal variabilities of the circulation in the western Mediterranean. Dyn. Atmos. Oceans 15: 179-214. http://dx.doi.org/10.1016/0377-0265(91)90020-G

Morán X.A.G., Taupier-Letage I., Ruiz S., et al. 2001. Physicalbiological coupling in the Algerian basin (SW Mediterranean): Influence of mesoscale instabilities on the biomass and production of phytoplankton and bacterioplankton. Deep-Sea Res. Part I 48: 405-437. http://dx.doi.org/10.1016/S0967-0637(00)00042-X

Mémery L., Reverdin G., Paillet J., et al. 2005. Introduction to the POMME special section: Thermocline ventilation and biogeochemical tracer distribution in the northeast Atlantic ocean and impact of mesoscale dynamics. J. Geophys. Res. 110: C07S01. http://dx.doi.org/10.1029/2005JC002976

Nihoul J., Jamart B. (eds). 1989. Mesoscale/Synoptic Coherent Structures in Geophysical Turbulence. Proceedings of the 20th International liège Colloquium on ocean hydrodynamics. Elsevier, Amsterdam.

Niiler P. 2003. A brief history of drifter technology. In: Autonomous and Lagrangian Platforms and Sensors Workshop. La Jolla, CA Scripps Institution of Oceanography.

Niiler P., Davis R., White H. 1987. Water-following characteristics of a mixed layer drifter. Deep-Sea Res. Part I 34: 1867-1882. http://dx.doi.org/10.1016/0198-0149(87)90060-4

Niiler P., Sybrandy A., Poulain P., et al. 1995. Measurements of the water-following capability of holey-sock and TRISTAR drifters. Deep-Sea Res. Part I 42: 1951-1964. http://dx.doi.org/10.1016/0967-0637(95)00076-3

Peña-Izquierdo J., Pelegrí J.L., Pastor M., et al. 2012. The continental slope current system between Cape Verde and the Canary Islands. Sci. Mar. 76S1: 65-78. http://dx.doi.org/10.3989/scimar.03607.18C

Reverdin G., Blouch P., Boutin J., et al. 2007. Surface salinity measurements COSMOS 2005 experiment in the Bay of Biscay. J. Atmos. Oceanic Technol. 24: 1643-1654. http://dx.doi.org/10.1175/JTECH2079.1

Reverdin G., Morisset S., Marié L., et al. 2015. Surface salinity in the north atlantic subtropical gyre during the STRASSE/SPURS summer 2012 cruise. Oceanography 28: 114-123. http://dx.doi.org/10.5670/oceanog.2015.09

Richardson P. 1983. Eddy kinetic energy in the north Atlantic from surface drifters. J. Geophys. Res. 88(C7): 4355-4367. http://dx.doi.org/10.1029/JC088iC07p04355

Roemmich D., Owens W. 2000. The Argo project: Global ocean observations for understanding and prediction of climate variability. Oceanography 13: 45-50. http://dx.doi.org/10.5670/oceanog.2000.33

Roemmich D., Johnson G., Riser S., et al. 2009. The Argo project: Global ocean observations for understanding and prediction of climate variability. Oceanography 22: $34-43$ http://dx.doi.org/10.5670/oceanog.2009.36

Rossby T. 2007. Evolution of lagrangian methods in oceanography. In: Griffa A., Kirwan Jr. A.D., Mariano A.K., et al. (eds). Lagrangian Analysis and Predictions of Coastal and Ocean Dynamics, Cambridge University Press. pp. 1-38. http://dx.doi.org/10.1017/CBO9780511535901.002

Ruiz S., Font J., Emelianov M., et al. 2002. Deep structure of an open sea eddy in the Algerian basin. J. Mar. Syst. 33-34: 179-195. http://dx.doi.org/10.1016/S0924-7963(02)00058-1

Ruiz-Villarreal M., González-Pola C., del Rio G.D., et al. 2006. Oceanographic conditions in the north and northwest Iberia and their influence on the Prestige oil spill. Mar. Poll. Bull. 53: 220-238.

http://dx.doi.org/10.1016/j.marpolbul.2006.03.011

Sabatés A., Olivar M.P., Salat J., et al. 2007. Physical and biological processes controlling the distribution of fish larvae in the NW Mediterranean. Prog. Oceanogr. 74: 355-376. http://dx.doi.org/10.1016/j.pocean.2007.04.017

Salas J. 2003. Evolution of the open-sea eddy ALGERS'98 in the Algerian basin with Lagrangian trajectories and remote sensing observations. J. Mar. Syst. 43: 105-131. http://dx.doi.org/10.1016/j.jmarsys.2003.08.001

Salas J., Millot C. Font J., et al. 2002. Analysis of mesoscale phenomena in the Algerian basin observed with drifting buoys and infrared images. Deep-Sea Res. Part I 49: 245-266. http://dx.doi.org/10.1016/S0967-0637(01)00052-8

Salat J. 2010. Agustí Julià i Brugués (1940-2009). Sci. Mar. 74: 197-201. http://dx.doi.org/10.3989/scimar.2010.74n1197

Salat J., Tintoré J., Font J., et al. 1992. Near-inertial motion on the shelf-slope front off northeast Spain. J. Geophys. Res. 97(C5): 7277-7281. http://dx.doi.org/10.1029/92JC00588

SOLAS. 1974. International convention for the safety of life at sea. International Maritim Organization (IMO). Available at: http://www.imo.org/en/About/Conventions/ListOfConventions/Pages/International-Convention-for-the-Safety-of-Lifeat-Sea-\%28SOLAS\%29,-1974.aspx

Sotillo M., Alvarez-Fanjul E., Castanedo S., et al. 2008. Towards an operational system for oil spill forecast over Spanish waters: Initial developments and implementation. Mar. Poll. Bull. 56: 686-703. http://dx.doi.org/10.1016/j.marpolbul.2007.12.021

Sotillo M.G., Cailleau S., Lorente P., et al. 2015. The MyOcean IBI Ocean Forecast and Reanalysis Systems: operational products and roadmap to the future Copernicus Service. J. Operational Oceanog. 8(1): 63-79. http://dx.doi.org/10.1080/1755876X.2015.1014663

Swenson M., Niiler P.P., Sybrandy A.L., et al. 1991. Feasibility of attaching seacats to TOGA drifter. Ref. Ser., Scripps Inst. of Oceanogr., La Jolla, Calif., pp. 91-30.

Swenson M., Niiler P.P., Sybrandy A.L., et al. 1992. Drifter observations of a cold filament off Point Arena, California in july 1988. J. Geophys. Res. 97(C3): 3593-3610. http://dx.doi.org/10.1029/91JC02736

Sybrandy A., Niiler P., Sombardier L. 1992. Technical improvements to the WOCE/TOGA lagrangian drifter. In: Proceedings of the OCEANS'92 conference on mastering the oceans Through Technology, volume 2, pp. 718-720. IEEE. http://dx.doi.org/10.1109/OCEANS.1992.607671

Wang D., Vieira M., Salat J., et al. 1988. A shelf/slope frontal filament off the northeast Spanish coast. J. Mar. Res. 46: 321-332. http://dx.doi.org/10.1357/002224088785113586

WMO 1988. WOCE surface velocity program planning committee report of first meeting: SVP-1 and TOGA pan-Pacific surface current study. World Climate Research Program Wormley: World Meteorological Organization. 33 pp. WMO/TD-No.323, WCRP-26. 